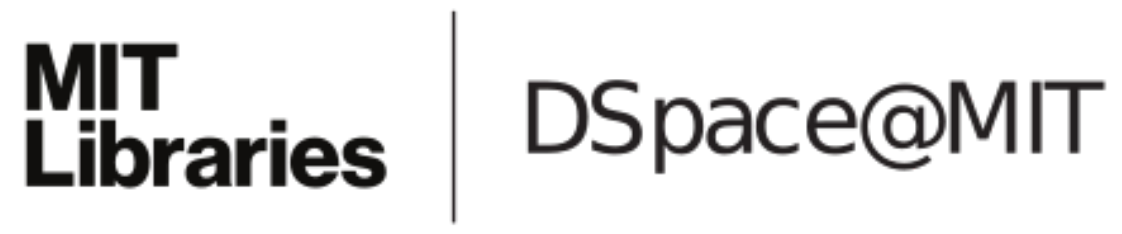

\author{
MIT Open Access Articles
}

Spatial Dependence in International Office Markets

The MIT Faculty has made this article openly available. Please share how this access benefits you. Your story matters.

Citation: Chegut, Andrea M., Piet M. A. Eichholtz, and Paulo J. M. Rodrigues. "Spatial Dependence in International Office Markets." J Real Estate Finan Econ 51, no. 2 (November 9 , 2014): 317-350.

As Published: http://dx.doi.org/10.1007/s11146-014-9484-x

Publisher: Springer US

Persistent URL: http://hdl.handle.net/1721.1/103609

Version: Author's final manuscript: final author's manuscript post peer review, without publisher's formatting or copy editing

Terms of Use: Article is made available in accordance with the publisher's policy and may be subject to US copyright law. Please refer to the publisher's site for terms of use. 
Noname manuscript No.

(will be inserted by the editor)

\title{
Spatial Dependence in International Office Markets
}

Received: date / Accepted: date

\begin{abstract}
This paper investigates spatial dependence in the prices of office buildings in Hong Kong, London, Los Angeles, New York City, Paris, and Tokyo for 2007 to 2013. Compared to prior literature, we find low economic impact from spatial dependence in all six markets, and spatial and spatialtemporal dependence do not moderate the effects of hedonic characteristics statistically or economically. However, investor and seller types as well as neighborhood location have a significant impact on the economic and statistical significance of the spatial and spatial-temporal parameters. Spatial office price indices for London, Paris and Tokyo decline somewhat more than do hedonic indices during the crisis.
\end{abstract}

Keywords Spatial dependence $\cdot$ Commercial real estate $\cdot$ Spatial autoregressive model $\cdot$ Spatial-temporal autoregressive model $\cdot$ Hedonic model

Address(es) of author(s) should be given 


\section{Introduction}

The market value of commercial real estate may depend on the value of comparable real estate assets within the local market. This may be a result of developers looking to their local competitors to incorporate similar building technologies; building codes that mandate homogeneous requirements; and a real estate boom during a particular period that leads to a concentrated commercial building stock of one typical cohort in a location. Investors, market analysts and appraisers likely consider local market conditions and local building comparables when doing building valuations and market assessments. In turn, building characteristics may be correlated in space and the price formation process of commercial real estate may be used, in part, by neighboring building transactions as pricing support, thus creating spatial correlation in prices.

When modeling the factors that drive commercial real estate prices, omitting spatial dependence from pricing models may misrepresent the extent to which a building's price is already correlated with that of its neighbors Anselin (1988); LeSage and Pace (2010). Not measuring spatial dependence can lead to omitted variable bias and potentially spurious economic inferences from other pricing factors. Moreover, the t-statistics and F-statistics of these pricing models could be biased, and economic inferences based on a building's characteristics may be erroneous in the event of spatial dependence in the error term Downs and Slade (1999). Lastly, any price index employing commercial real estate attributes, like in the hedonic model, may be biased if the spatial dependence of prices is associated with macro-economic conditions.

Spatial dependence has previously been tested in commercial real estate through spatial and spatial-temporal autoregressive models. Spatial autoregressive models measure the co-movement between transaction prices of neighboring properties, while spatial-temporal autoregressive models measure the co-movement of transaction prices with transactions that are close in space as well as time. So, these models capture the impact of recent and near transactions on an office property's transaction price.

Previous work by Tu et al (2004) investigated spatial dependence for the Singapore office market using a spatial-temporal autoregressive model. The results indicate that the spatial dependence parameter is large, positive and statistically significant. Moreover, their findings suggest that spatial dependence is also relevant for transaction price indices. Nappi-Choulet and Maury (2009) studied the spatial dependence of the Paris office market and found evidence of large, positive and statistically significant spatial dependence as well. The methodology for both analyses is derived from Pace et al (1998) whose housing study was the first to implement a spatial-temporal autoregressive model in real estate.

To our knowledge, Tu et al (2004) and Nappi-Choulet and Maury (2009) are the only two papers that study spatial dependence in commercial property

prices and the evidence for the presence of spatial dependence in commercial real estate is limited. Moreover, Geltner and Bokhari (2008) noted that spa- 
tial dependence may not be a significant factor in commercial real estate as segmentation across commercial property markets is very high. The sparsity of research in this area can be explained by a lack of transaction data in commercial real estate. However, recent advances in data collection open the way for new research in the relationship between real estate transaction prices and spatial-temporal dependence.

The aim of this paper is to employ a new global database of commercial property transactions to question whether spatial dependence is an important factor in hedonic models and price indices. In addition, we investigate what formulation of the model, spatial or spatial-temporal, is best for filtering out the potential spatial correlation between building prices and to what extent this influences hedonic based commercial property price indices.

We first employ a simple hedonic model as a benchmark against which we will compare the subsequent model specifications. Then, in line with the literature, we employ a spatial autoregressive (SAR) and spatial-temporal autoregressive (STAR) model. However, in contrast to the literature, we add controls for spatial dependence in the error term (AR) to specify SARAR and STARAR models, respectively. These models are applied to the office markets of Hong Kong, London, Los Angeles, New York City, Paris and Tokyo for 2007 to 2013. Globally, these six markets are ranked in the top 10 markets with the highest investment volume. ${ }^{1}$

Results indicate that spatial dependence in these markets as estimated by the SARAR and STARAR models is statistically significant, but economically of limited importance. For London, Paris, Tokyo and New York City spatial dependence is statistically significant, but has a very small regression coefficient. In Tokyo, we find evidence of statistically significant spatial-temporal dependence on top of that, but here also, the economic significance is small. For Hong Kong and Los Angeles, our spatial and spatial/temporal estimations do not result in statistically significant parameters.

We also looked at the significance of spatial and spatial-temporal dependence for Central Business Districts in London, Tokyo and New York City individually. Results of these estimations confirm our previous findings. In Tokyo, we find the strongest evidence of the presence of spatial and spatialtemporal dependence, but the economic effects are very small. Lastly, the indices constructed from the hedonic, SARAR and STARAR models suggest indices based on the latter models declined somewhat more in value than the hedonic indices in the initial stage of the crisis.

The remainder of this paper is structured as follows. Section 2 reviews the literature on spatial analysis and commercial real estate with an emphasis on understanding the motivation for including spatial dependence in commercial real estate analysis. Section 3 provides the estimation strategy, SARAR and STARAR models. Section 4 covers the sources and descriptive statistics of the global office market data. Section 5 contains the results of the analysis,

\footnotetext{
1 See the Real Capital Analytics Ranking tool lists global property markets and players by transaction volume on a rolling 12 month window.
} 
including the regression output of the hedonic, SARAR and STARAR models and a look at where spatial and spatial-temporal models may play a role in property price indices. Section 6 provides a discussion and section 7 concludes.

\section{Spatial Dependence in Commercial Real Estate}

\subsection{Global Hedonic Literature}

The base model for measuring the systematic factors contributing to the value of commercial real estate is the hedonic valuation framework. ${ }^{2}$ Starting with US based studies, Fisher et al (1994) compared three commercial property index construction methods for the 1982 to 1992 period: an unsmoothed US Russell-NCREIF Index, an unlevered REIT shares index and a hedonic index. This first hedonic application to commercial real estate gave the first look at the ex-post transaction-based trends in the market place and demonstrated that transaction-based indices led appraisal-based indices in turning points in the market place. ${ }^{3}$ Later, Colwell et al (1998) applied this method to Chicago office property transactions between 1986 and 1993, using a much broader set of building characteristics. ${ }^{4}$

To eliminate data issues surrounding individual hedonic characteristics, Fisher et al (2007) estimated a hedonic model for US institutionally held real estate that included the most recent appraisal of the transacted properties as an estimate of a hedonic bundle of goods and services embedded in a property. ${ }^{5}$ This method is useful when building quality data is scarce. However, as US databases have started to collect more data over the 2000s, the possibility of a more elaborate hedonic model based on building and location characteristics became possible for more cities. Examples are Eichholtz et al (2010) and Eichholtz et al (2013), who expanded the hedonic model for US office property with a broader set of building characteristics.

Internationally, Tu et al (2004) measure the value of Singapore office units between 1992 and 2001 ${ }^{6}$, while Nappi-Choulet and Maury (2009) study Paris

\footnotetext{
2 Fisher et al (1994) were the first to apply the hedonic framework to commercial real estate. Since that time, there have been approximately 20 studies that study commercial property markets through the hedonic framework. However, most of these studies look at realized rents or asking rents. Just under ten studies look at transaction prices in commercial property and a majority look at property price trends in the US.

3 Fisher et al (1994) specify a hedonic model that measures the variation in price per square foot through property type, function, location, quality, local income, population, net income and capital expenditures of the owner.

4 Colwell et al (1998) extended the hedonic model for Chicago office property by including more building characteristics, e.g., age, lot area, size and height, and more neighborhood characteristics, e.g. distances to airport, rail and road facilities as well as golf-courses to explain the variation in the log price per square foot.

5 There are other neighborhood and time components included in the study: metropolitan area dummies and property type dummies.

6 Tu et al (2004) includes the floor area of the office unit, the age of the unit, the floor level where the office unit is located and whether the unit was leasehold to explain the variation
} 
office prices over the 1992 to 2005 period. Devaney and Diaz (2011) replicate Fisher et al (2007) for the UK and include appraised value along with property type and location to explain the variation in prices between 2002 and 2010. Chegut et al (2014) broaden the set of building characteristics in their hedonic model to estimate the value of green buildings in London over the 2000 to 2009 period. ${ }^{7}$ With the ongoing development of commercial property databases, this literature is set to develop further in the future.

\subsection{Models of Spatial Dependence in Commercial Real Estate}

A primary motivation to extend the hedonic model is to account for spatial dependence between commercial real estate assets, which aims to account for adjacency effects - spillovers between transaction prices - rather than filter the absolute price differences between locations by neighborhood aggregation. Spatial econometric models are an extension of conventional regression models, and include a spatial component that is able to capture the potential dependence caused by the interaction with neighboring observations. This form of dependence is often found in data regarding observations that are characterized by their location Anselin (1988); LeSage and Pace (2010).

Within the spatial literature there are a number of econometric motivations for including a spatial autoregressive parameter. First, if spatial dependence is present, the outcomes of a conventional hedonic model are biased where space is correlated with other factors. There is an omitted variable bias which arises when the data exhibits spatial dependence that is not captured by the model. Hence, it is important to take this potential dependence into account. Pace et al (2000) find that the correlation between the housing assets and the reference group decreases substantially, almost to zero, while there is still correlation present when the non-spatial regression model is applied. Second, se Can and Megbolugbe (1997) show that there is spatial dependence in the housing market and determine that this is driven by spatial externalities or locational effects.

Tu et al (2004) apply the spatial regression methodology to the construction of a commercial real estate index in Singapore. Their results indicate that by allowing for spatial dependence in their hedonic model the spatial based index of the office market in Singapore captures standard hedonic properties as well as spatial dependence for the market and structurally changes the office price index by a five to ten percent difference conditional on the property cycle. Nappi-Choulet and Maury (2009) apply this methodology to the office market in Paris. This study focuses on the two main business districts in Paris and finds significant spatial dependence and evidence of a temporal break in the time dependence of Parisian properties. Still, the spatial dependence

in transaction prices. Nappi-Choulet and Maury (2009) document for Parisian sub-markets size, age and period of construction to explain variation in prices.

7 Chegut et al (2014) broaden their controls to include transportation networks, investor types and per unit building quality characteristics to explain the price per square foot. 
tends to be more significant than the temporal dependence, but the resulting index differs by zero to ten percent across property cycles from the traditional hedonic-based index.

Consequently, there is evidence that suggests that transaction prices could be spatially dependent upon each other. If this factor is important in understanding the price formation process, then it is important that future research begins to take into consideration these models, which is what we do in this paper. Moreover, richer data environments are ever increasing in the commercial property sector, making these models on the one hand feasible and on the other hand more relevant. Since prices of commercial properties seem to be driven by both location and structural factors, it is as yet unclear whether transaction prices could be spatially dependent upon each other.

\section{Model Specification and Estimation}

\subsection{Model Development}

In the hedonic model the price of a building is a weighted sum of the building characteristics. The hedonic theory proposed by Rosen (1974), models the constant-quality price index for products based on the utility that they provide to the consumer. The method relates the price of a product to the product's individual components, much like the pricing of an equity portfolio, which is given by the weighted sum of the stock prices included in the portfolio. The difficulty is to find the hedonic value of each characteristic pertaining to the building, these are found by means of a linear regression using the price as the dependent variable. To use this approach to identify the individual pricing components of a building asset and for the construction of a commercial real estate price index, we include hedonic building characteristics, building location and time dummies into the regression model, which capture building and location effects of the asset as well as the trends pertaining to the year in which the transaction took place.

The first model in our analysis is given by the standard hedonic framework as originally specified by Rosen (1974) and which is specified as follows:

$$
\log P=X \beta+T \delta+\epsilon,
$$

where $P$ is an $n \times 1$ vector of logged property transaction prices per square foot, $X$ is an $n \times k$ matrix of (exogenous) hedonic property characteristics; $\beta$ is a $k \times 1$ parameter vector, $T$ is a $n \times t$ matrix containing time dummies, and $\epsilon$ is the $n \times 1$ vector of regression disturbances. ${ }^{8}$ To give context to this notation

\footnotetext{
8 The hedonic literature is inconsistent in its usage of log price or price per square foot. However, given the heterogeneous size of buildings within our sample and the cross sample differences in building customs, we follow Fisher et al (1994) and Fisher et al (2007) who estimate models using price per square foot to control for cross-market building size heterogeneity. Moreover, size is correlated with other hedonic factors, e.g., age or stories, and without filtering for size reflects a size and hedonic attribute component.
} 
with regard to the commercial property data, we note that $n$ denotes the number of observed transactions, $k$ denotes the number of hedonic building characteristics we observe, including neighborhood aggregation effects, and $t$ denotes the number of years that our data set encompasses. The model given in Equation (1) is our baseline model to which we compare the spatial specifications.

In a second step, we augment the hedonic model by including spatial interactions with neighborhood price dependence. Thus, the transaction prices are a function of the building's hedonic characteristics, neighborhood aggregation effects, macro-economic conditions and the addition of spatial dependence in the form of past prices of neighboring buildings. In line with the spatial autoregressive (SARAR) model specified by Kelejian and Prucha (2010), the model is given as follows:

$$
\begin{aligned}
\log P & =\rho_{1} W \log P+X \beta+T \delta+\epsilon, \\
\epsilon & =\lambda W \epsilon+u,
\end{aligned}
$$

where the new elements in this equation relate the price of the building to a spatially lagged price, with $W$ denoting a $n \times n$ weight matrix that measures the physical distances between the transacted buildings. Each row in the matrix pertains to a transaction in our data set. In the event that an element in this row is different from zero, i.e., it is not the same building, the column of this non-zero element gives a nearby transaction's inverse distance measure. In this way, each transaction's price is related to the neighboring price observed in the same row.

It is common in the literature (Pace et al (1998); Tu et al (2004); NappiChoulet and Maury (2009)) to set the elements in the weight matrix as a function of the physical distance between the observations and we follow this procedure. We set the weight equal to the inverse distance in kilometers between two objects, where distance is measured as the shortest distance between two buildings measured by using the coordinates of the location of the buildings. Furthermore, it would not be sensible to relate a price observation to another transaction that occurs later in time. We therefore set all weights relating to a particular transaction that occurs in the future to zero, ensuring that our model conforms to the information set an investor would have at his/her disposal.

From a spatial econometrics perspective, spatial dependence may arise in both the model and the disturbance structure. Spatial dependence could arise in the disturbance structure caused by spatially correlated unobserved variables (LeSage and Pace (2009); Kelejian and Prucha (2010)). The spatial disturbance structure is new in the application of spatial econometrics to commercial real estate. The SARAR specification captures the spatial dependence in both the model and the disturbance structure Kelejian and Prucha (2010). In this specification, the error term is modeled so that it also exhibits possible spatial autocorrelation. We also allow for possible heteroskedasticity in the 
errors, so that this specification is fairly general. Note that the weight matrix used in the error term is equal to the weights used in the explanatory model component.

Econometric theory imposes a limit of spatial dependence in that the further away the observations are the less correlation they exhibit, so that eventually they are uncorrelated. This assumption also makes economic sense, in that two transactions that are very far apart have limited influence on each other. We impose this restriction, in that we only set the weights of the nearest neighbors different from zero. Elhorst et al (2012) documents that the specification of the weight matrix is significant for identifying spatial dependence. Consequently, the spatial weight matrix is specified with three distinct nearest neighbor cut-offs of five, 10 and 15 nearest neighbors whilst calculating the inverse distance between the neighboring building and transacted building.

The third model relates the price of buildings to prices that are close in time, as well as in space and time. This model accounts for three price search processes; buyers and sellers may take transactions of buildings into consideration that occurred close by in physical space, in time, and in space and time. The spatial-temporal autoregressive (STARAR) model is specified as follows:

$$
\begin{aligned}
\log P & =\rho_{1} W \log P+\rho_{2} L \log P+\rho_{3}(W \odot L) \log P+X \beta+T \delta+\epsilon, \\
\epsilon & =\lambda W \epsilon+u
\end{aligned}
$$

where notation follows in large part the specification given in Equation (2) adding the components $\rho_{2} L \log P$ and $\rho_{3}(W \odot L) \log P$ and $\odot$ denotes the element by element multiplication of matrices.The matrix $L$ has dimensions $n \times n$ and captures the pure time dimension in the relationship between transactions. We set the elements equal to the inverse distance in time between observations, with distance measured in days. Again, we only set the elements of the nearest neighbors not equal to zero to limit the degree of cross-sectional correlation. Like in the specification of the spatial weights we use five, 10 and 15 nearest neighbors. The term $(W \odot L)$ measures a combined effect of space and time, in that observations that fulfill both requirements to be considered have a higher weight in the equation. ${ }^{9}$ The spatial error follows Equation (3). More details on the estimation procedure are provided in the Appendix B.

\section{Global Commercial Office Markets}

We study spatial dependence in six major office markets: London, Paris, Tokyo, Hong Kong, New York City and Los Angeles. These cities represent the two largest office markets by transaction volume in Europe, Asia and the Americas, respectively. All six of these markets have enough transaction volume for meaningful statistical inference.

\footnotetext{
${ }^{9}(W \odot L)$ specifies the weight by using both the space and time of the nearest neighbor. It also ensures that each observation relates to its own nearest neighbor observation and not the neighbors of other buildings.
} 
We use office transaction data from Real Capital Analytics (RCA). RCA is an international property research firm with a focus on the investment market for commercial real estate. RCA started to track the transactions of commercial real estate in the US in 2001, and began tracking international transactions in 2007. Importantly, RCA only collects global market data for properties that transact for more than US $\$ 10 \mathrm{mln}$. Thus, we analyze properties primarily traded by institutional investors. Data collected by RCA across all markets are transaction prices, transaction dates, common building characteristics, investor and seller types, the physical location of the building and information on whether the transaction is a part of a portfolio transaction. We filtered out the transactions of properties that were part of a portfolio sale and properties that flipped within six months of the initial transaction. Moreover, we only regard observations for which we have a full set of hedonic and location characteristics.

\section{-Place Table 1 about here.-}

Table 1 documents the descriptive statistics: the mean and standard deviation of the transaction prices (in US \$) and hedonic characteristics of the six office property markets from 2007 to 2013. The table also gives sample sizes, and shows that the number of observed transactions ranges from 492 for Paris to 1316 for Tokyo. The sample period covers the Financial Crisis and the European Sovereign Debt Crisis. Although the number of transactions in the sample is relatively stable in time, we do observe lower liquidity in some years due to these economic crises.

We see wide variation in mean transaction prices and standard deviations across property markets. Within this sample, London has the highest mean transaction price at US $\$ 138.4 \mathrm{mln}$ and Hong Kong's office market has the lowest at US $\$ 45.2 \mathrm{mln} .^{10}$ The market with the greatest variation in transaction prices is New York City. However, markets have varying mean building sizes, so to scale building size heterogeneity, we divide the transaction price by the size of the building, to get prices per square foot. These numbers continue to suggest that London is expensive, with prices averaging US $\$ 1,119$ per square foot. However, on a price per square foot basis, Hong Kong's office market is the most expensive, with an average price of US $\$ 1,464$.

Turning towards individual building characteristics, we look at the average age of office space in the sample. ${ }^{11}$ Surprisingly, the average oldest space is in New York City at 62 years, which is quite a lot older than London and Paris space that is 50 and 51 years old on average, respectively. However, the age dispersion is very high for London and Paris at 64 years, but much less for New

\footnotetext{
10 Data on Hong Kong's office market reflects office condos as opposed to full building transactions.

11 Within the model we specify age and $a g e^{2}$ as these explain the depreciation component of the variation in transaction prices. Bokhari and Geltner (2014) document for US markets the impact of depreciation on commercial property values over the 2001 to 2013 period. The proportion of prices explained by depreciation varies across markets, but is economically significant across US markets.
} 
York City at 34 years. Tokyo, Hong Kong and Los Angeles have much younger office markets. These mean ages correspond with the development booms in each of the markets, where the office markets of London and Paris were already well-developed in the postwar era of the 1960s and 1970s and Tokyo and Hong Kong's in the 1980s and 1990s. New York City and Los Angeles have varying periods of development and expansion. New York City's office development started in the late 1900s, slowed down a bit by the 1950s, but is still going on, whereas Los Angeles' market started to expand and develop only in the 1970s and 1980s. This also corresponds with the extent of building renovation, where new markets have the smallest proportion of renovation and older markets like New York City have the most renovation.

In terms of building height, the tallest offices in the sample are located in Hong Kong, with an average of 31 stories. Yet, it is also the market with the fewest number of buildings. This seems to be driven by the scarcity of space on Hong Kong Island. New York City and Tokyo share similar story characteristics, with moderately high buildings. However, London, Paris and Los Angeles have less skyscrapers than the other markets. In the traditional business districts of London and Paris, building regulations and architectural norms kept buildings relatively short. Moreover, these cities are not constrained by natural boundaries, and in principle, they can expand in many directions, as is illustrated by the development of large new office markets in Canary Wharf in London and La Defense in Paris. In contrast, Hong Kong and New York City's development space is limited by their natural boundaries.

Bokhari and Geltner (2011) document for US commercial property that different institutional investors anchor their bid and ask prices in the market place and that this impacts relative transaction prices. Later Devaney and Diaz (2011) and Chegut et al (2014) document that investor types are important in filtering out price differences in the hedonic model. We therefore include investor and seller types in our models. RCA defines six investor or seller types. Equity funds are capital market investors in real estate. Institutional investors tend to be pension funds or insurance companies. Private represents private real estate companies. Public represents publicly traded real estate companies, including real estate investment trusts. Owner occupied stands for investors who own and operate their own building, and unknown stands for firms that are empty in the database. Investor capital is mainly supplied by pension funds and public or private real estate firms. In London and Paris the primary investors and sellers are institutional investors like pension and sovereign wealth funds, and public and private investors pick up the remaining share. In Tokyo, Hong Kong and New York City public and private real estate investment firms account for at least 60 percent of the trades in the sample and mainly institutional investors rather than owner occupiers dominate the sample. 


\subsection{Neighborhood Effects}

An important component of existing hedonic studies is the inclusion of neighborhood effects, and we follow that tradition. To account for these effects, the model includes sub-market dummies to control for cross-market locational heterogeneity. Moreover, we add a Central Business District (CBD) dummy.

Figure 1 displays the distribution of transactions in each property market, and illustrates how distinct these markets are in terms of building concentration. See Appendix A for detailed information regarding the sub-market dummies and CBD definitions. Except for Los Angeles, these maps cover an area of approximately 6 by 9 miles (9.6 by 14.4 kilometers). Some, like London and New York City show very concentrated patterns, while the samples in Paris, and especially Los Angeles are spread out over a much greater area. Figure 1a depicts London's City, West End, South of the Thames and Docklands neighborhoods distinctly and shows a very high density of transactions in London's CBD: the City. Figure 1b depicts a more diverse spread for Paris, with some clustering in the 8th Arrondissement, which is Paris's CBD.

Figure 1c depicts Tokyo's office market, showing how the Chiyoda, Chuo, Minato and Central Wards form a donut ring around Tokyo's Imperial Palace. Figure 1d highlights the clustering of buildings along Hong Kong's northern shore. It is predominantly here that buildings are able to cluster due to the mountain range behind them. Land for skyscraper development is not available elsewhere.

Figure 1e depicts the prominence of Manhattan Island in the New York metro area, where Midtown and Lower Manhattan dominate institutional office transactions. Compared to that, office transactions in the other boroughs and across the river in New Jersey are limited. Lastly, Figure 1f highlights the sheer scale of Los Angeles' office market. In contrast to the other maps, this map shows no distinct central location for the Los Angeles metro area. Moreover, the Los Angeles map covers an area of 96 by 144 miles (153.6 by 230.4 kilometers), which is 16 times greater than the other five maps. This illustrates the uniqueness of Los Angeles in terms of (its lack of) office market concentration.

-Place Figure 1 about here.-

\section{Spatial and Spatial-temporal Dependence}

Results for the hedonic, SARAR and the STARAR models are reported in Tables 2 through 4 . For all markets, we operationalize the models with controls for hedonic characteristics, buyer and seller types, time fixed-effects, city-specific neighborhood dummies and measures of spatial and temporal dependence. In line with the spatial literature, we test across three nearest neighbor specifications of the spatial, temporal and spatial-temporal weighting matrices.

General results documented across all markets suggest that spatial and spatial-temporal dependence are positively and statistically significantly re- 
lated to explaining the price variation in the transaction prices per square foot. However, economically, the factors do not seem to play an important role. Across all markets, the proportion of transaction price per square foot explained by spatial or spatial-temporal dependence is about .12 percent. For example, in London just over one dollar of the average $\$ 1,119.45$ paid per square foot is explained by spatial or spatial-temporal dependence, ceteris paribus. $^{12}$

In addition, the changes in the hedonic and investor type parameter estimates across models are quite marginal. Specifically, for London, Paris and Tokyo, time fixed-effects parameters are on average greater across spatial and spatial-temporal models relative to hedonic specifications for 2007 to 2009 . However, this impact is not seen during the Financial Crisis and Hong Kong, New York City and Los Angeles do not exhibit differences across specifications.

Results documented here are largely in line with the previous literature using hedonic approaches to model the variation in the log price per square foot for other real estate markets. Our models have comparable explanatory power, with an adjusted $R^{2}$ of just under 50 percent. However, there is one exception, and that is Tokyo, where the fit of the model is approximately 24 percent. The fit of the models does not improve from a hedonic to a spatial or spatial-temporal specification.

Lastly, the inclusion of city-specific neighborhood characteristics apparently plays a critical role in the price formation process of commercial real estate. Filtering on the location of a building almost doubles the explanatory power of the model. In addition, omitting neighborhood characteristics impacts the estimation of average price effects in any given year. Moreover, the spatial and spatial-temporal dependence parameters become significantly larger, suggesting a correlation between adjacency and neighborhood effects. More importantly, the spatial error term increases substantially in magnitude with any omission of neighborhood effects, which suggests that building location and other omitted variables from the specification are correlated.

We will now present the estimation results for the different specifications for each market individually, beginning with those in Europe, and then moving on to Asia and the United States. In addition, for the three largest markets globally, London, Tokyo and New York City, we include a sub-specification for the CBD. To not overload the paper with too many results, we limit our discussion of the parameter estimators to one specification of the spatial and temporal weight matrices, namely to the five nearest neighbors. For robustness, we ran all specifications across all weight matrices, with and without neighborhood effects and excluding investor and seller types. The results for the remaining weighting specifications are not materially different, but the results for specifications that exclude neighborhood effects and investor and seller types are materially different and they tend to inflate other hedonic

\footnotetext{
12 The calculation for the average spatial dependence effect estimated by Equation 3 is specified as follows: when calculated at the mean $\rho \sum_{i=1}^{J=N} W_{i j} \log P_{j}$ this yields $\$ 1.39$ for the London office market, ceteris paribus.
} 
characteristics in the specification except spatial dependence. All specification tests not provided in the paper are available upon request.

\subsection{European Markets}

Table 2 depicts the results of the hedonic and spatial specifications for London and Paris. The first three columns show the results for London. Column (1) shows results of the standard hedonic OLS estimation. This model explains 44 percent of the variation in the log price per square foot of London's investmentgrade office stock. Log size is negatively related to price, suggesting modestly decreasing returns to scale when size increases - as size increases by 1 percent the transaction price per square foot declines by just over 0.10 percent. London stands out relative to the other five markets in the prices paid by the different buyers: all investor types buy for less than the owner-occupiers. Equity funds and private and public real estate companies buy properties for 25, 36 and 25 percent less, respectively. In the other five markets, either owner-occupiers seem to be the savvy buyers, or we see no significant differences between this category and the others. In 2009 and 2013, buildings traded for 61 and 37 percent below prices in 2007. London's market saw small gains in 2012 and 2013, but does not seem to have fully recovered from the Financial Crisis.

-Place Table 2 about here.-

Column (2) reports the results of the SARAR model for the specification with five nearest neighbors. Both the spatial error and spatial parameters are economically small, but statistically significant. Log size remains negative and statistically significant. Buyer and seller type coefficients remain similar as in the hedonic specifications. However, filtering for spatial dependence has shifted the relative magnitude and statistical significance of transactions in 2008 and 2009. After filtering for spatial dependence, relative transaction prices in these years were higher than in the hedonic specification, which indicates a slight deviation across estimated price indices.

Column (3) reports the results of the STARAR model, again with five nearest neighbors. Added to the spatial autoregressive model is a filter for general temporal dependence between transactions across the sample and neighborhood, and for localized spatial-temporal dependence. Spatial dependence remains economically of little importance, but increases slightly in magnitude and retains its statistical significance. Here the size parameter decreases marginally with the addition of the temporal and spatial-temporal autoregressive parameters.

Columns (4) to (6) depicts results of the hedonic and spatial specifications for the Paris market. Log size, as was the case for London, is negatively related to price. However, the magnitude of the parameter is lower and is in fact the lowest across all property markets. Renovation status is important: renovation implies a 17 percent increase in the price per square foot. Buildings located in 
the CBD sell for a very high premium of 72 percent. Transaction prices have not yet rebounded to their pre-crisis levels.

Column (5) reports the results of the SARAR model for Paris. As was the case in London, the spatial dependence parameter is statistically significant, but not very important economically. The magnitude of the hedonic regression coefficients is not materially affected by the inclusion of this new parameter. In contrast to London, the inclusion of spatial dependence does not affect the development of the price index. Column (6) reports the results of the STARAR model. Spatial dependence is positive, but remains economically small. These results suggest that there is little impact from spatial dependence in the Paris office market between 2007 and 2013.

\subsection{Asian Markets}

Table 3 provides results of the hedonic and spatial specifications for Tokyo and Hong Kong. The first three columns show the results for Tokyo. In the standard hedonic OLS specification shown in column (1), we find that a one percent increase in floor area decreases the price per square foot by .21 percent. Age is also an important factor, and aging by one year decreases the transaction price by about 2.58 percent per square foot, which is by far the highest depreciation rate of the six market we study. However, the coefficient for the quadratic age term suggests a turning point after about 32 years, so buildings older than that (18 percent of the sample) seem to ripen with age. ${ }^{13}$ Moreover, taller buildings have higher transaction prices, where a one story increase of a building increases the price per square foot by 0.89 percent. Renovated buildings, which make up just a small proportion of the sample, receive a 22 percent increase in the price per square foot. Properties that trade in the CBD do so for 20 percent more per square foot. Institutional and public real estate companies buy for an average of 12 and 14 percent more, respectively, than the owner occupier sample. The time dummies show that Tokyo's office prices did not go down in the global crisis, but have fallen significantly only in 2012 and 2013 .

-Place Table 3 about here.-

Column (2) reports the results of the SARAR model for Tokyo. As before, the spatial dependence parameter is economically insignificant, but statistically significant, and does not materially affect the hedonic coefficients. That also holds for the results of the STARAR model reported in column (3).

Columns (4) to (6) show the results for Hong Kong offices. The hedonic model explains 57 percent of the variation in the log price per square foot. In the even more spatially constrained market of Hong Kong, scale economies play a more important role, where a one percent increase in a building's square

\footnotetext{
13 Komatsu and Shimazu (2003) document high levels of depreciation for commercial property in Tokyo.
} 
footage decreases the price per square foot by .23 percent. On the other hand, we do find quite a sizeable premium on tallness: a one story increase of a building increases the price per square foot by 1.21 percent. Last, transaction prices in the Hong Kong market have been steadily on the rise between 2007 and 2013: the price per square foot has increased by 69 percent since 2007 . This increase in prices is distinct from the other five property markets, where transaction prices per square foot have declined relative to 2007.

In columns (5) and (6), we report the results of the SARAR and STARAR specifications. Spatial and spatial-temporal dependence are statistically insignificant, and the hedonic characteristics, investor and seller types remain constant across specifications.

\subsection{North American Markets}

Table 4 shows the results for the markets of New York City and Los Angeles. The first three columns present the results for New York. The hedonic model explains 52 percent of the variation in the log price per square foot. In line with the existing hedonic literature and in line with the other cities, log size is negatively related to price, suggesting economies of scale as size increases. In fact, the size factor for New York is the largest of the six office markets we study. As the number of stories increases, transaction prices per square foot increase by .94 percent. The renovation status increases transaction prices by 17 percent per square foot. In New York, the owner occupiers seem to be the savvy investors, since all other buyer categories pay (significantly) more for their offices. Equity funds, institutional, public, and unknown buyers buy properties for 24, 28, 36 and 60 percent more, respectively. Moreover, relative to sellers who are owner occupiers, unknown and private real estate investors sell real estate for 49 and 12 percent less.

Relative to 2007, transactions occurring between 2009 and 2013 were priced significantly lower, but prices have been steadily increasing since 2010. In other words, New York is recovering from the Financial Crisis.

\section{-Place Table 4 about here.-}

Columns (2) and (3) report the results of the SARAR and STARAR specifications for New York, and show that the spatial dependence parameter is positive and statistically significant. In contrast to the previous markets, the spatial-temporal dependence parameter is also statistically significant albeit weakly. As before, the economic effect of these variables is small, and the hedonic coefficients are not affected. Thus, spatial and spatial-temporal dependence are statistically significant, but economically irrelevant.

Lastly, columns (4) to (6) depict the results for the hedonic and spatial specifications for Los Angeles. Los Angeles pays a premium on size similar to that of Hong Kong where for a one percent increase in square footage there is a 21 basis point decrease in price per square foot. Surprisingly given the layout of the Los Angeles office market, there is a large premium for taller 
buildings, even outstripping the premium we find in Hong Kong. A one story increase leads to a higher price per square foot of 1.6 percent, ceteris paribus. Also, Los Angeles offices depreciate at a far faster rate than those in New York City and approach the depreciation level of Tokyo. Lastly and suprisingly, Los Angeles offices that are located in the CBD, which comprises the new and old downtown markets in the metropolitan area, sell at a discount relative to offices in other submarkets.

Columns (5) and (6) report the results of the SARAR and STARAR specifications and these suggest that spatial dependence is statistically and economically insignificant across all specifications, and the inclusion of spatial terms alters the time dummy coefficients for the Los Angeles market even less than in New York and Hong Kong. So spatial effects do not seem to play an important role in Los Angeles office prices.

\subsection{Office Market Indices}

For all six markets, the results documented so far suggest that spatial and spatial-temporal dependence only affect the time dummy parameter estimates significantly. Figure 2 documents the transition that the time parameters make for the three models from 2007 to 2013, and for all six markets. Across all specifications, the index uses 2011 as the base year. The thick dashed line represents the index from the SARAR model, the small dots represent the STARAR model and the solid line reflects the index from the hedonic model.

Panels (2a) and (2b) document the office property price indicators for London and Paris. In London, the relative peak in the market occurred in 2007 across all specifications. However, the range of index levels varies substantially across specifications. After filtering for spatial or spatial-temporal dependence, price levels relative to the hedonic specification are 20 to 30 percent higher in 2007, suggesting a much stronger fall in average value due to the crisis. However, that margin decreases substantially as we move towards 2009 and 2010. Paris demonstrates a similar pattern, but the decline in property index levels from peak to trough is less than that of London, and the effect of the spatial dependence filter is much weaker.

Panels (2c) and (2d) show the index levels for Tokyo and Hong Kong, respectively. In contrast to the London and Paris markets, Tokyo and Kong Kong exhibit a small spread across model specifications. Filtering for spatial and spatial-temporal dependence does increase the index level for 2007, but the index levels quickly converge and remain so for 2009 to 2013. In Tokyo, transaction prices have gradually fallen year over year, but these have shown a steady upward trend in Hong Kong, where price levels for office property are now 40 percent higher than in 2007 and 2009.

Panels (2f) and (2e) depict the index levels for New York City and Los Angeles, respectively. The New York City results show that controls for spatial and spatial-temporal dependence have little impact on the index, but in 2012

the indices begin to spread marginally. The same conclusion holds for Los 
Angeles: spatial dependence does not affect index outcomes significantly. The relative peak in the Los Angeles series is in 2007, where price index levels are 50 percent greater than in 2010. The Los Angeles market bottomed out in 2009, with transaction prices 20 percent lower than in 2010 .

The overall picture that emerges is one of little variation between the indices for different specifications. In general, the spread in the property price indices, if present, takes place in the 2007 to 2008 period or in 2013. In contrast to previous studies on spatial dependence, this analysis focuses on six main commercial property markets over the period during and after the Financial Crisis, allowing us to compare the price paths of these six markets directly in a very unstable period.

-Place Figure 2 about here.-

\section{Discussion}

We find statistically significant evidence of spatial dependence for the six largest office property markets, but the estimated parameters suggest a weak economic impact on transaction prices. We also find some evidence of an impact of spatial dependence on the formation of hedonic price indices, but again, the effects are small.

A possible interpretation of these results lies in the time period we study. The fact that the Global Financial Crisis is in the heart of our sample period may influence the impact of the price of nearby buildings. In a stable market, a nearby transaction price is useful information to set a bid or an ask price for a building. However, when markets are very volatile, as they have been in the crisis, using these comparables becomes much more difficult. So the information spillover from nearby transactions may cease to be important in these circumstances.

In fact, this argument may also explain why our conclusions are so different from those of Tu et al (2004) and Nappi-Choulet and Maury (2009). Both these studies cover a complete office market cycle, but these cycles were of a "normal" magnitude and lacked the level of uncertainty surrounding the Financial Crisis. This could mean that market participants could more usefully employ comparables in the market circumstances covered in $\mathrm{Tu}$ et al (2004) and Nappi-Choulet and Maury (2009), resulting in a larger proportion of transaction price variation being explained by spatial dependence. Specifically, Tu et al (2004) create hedonic and STAR modeled price indices for Singapore between 1992 and 2001. Their results cover one real estate cycle, with expansion, peak, decline and expansion again. Peak to peak occurred over the 1997 to 2000 period, and the results show that the relative decline in 1997 for the Singapore office market was not very severe. Similarly, Nappi-Choulet and Maury (2009) estimate and index for Paris between 1992 and 2005, also covering one real estate cycle, which like Tu et al (2004) for the Singapore office market was also a lacking a crisis period for comparison. 
On the other hand, we do have one rather stable market in the sample: Tokyo. The fact that we do not find economically significant effects of the spatial dependence in that city suggests that our results could be generalized to stable market situations.

\section{Conclusion}

Our work contributes to two streams of literature. First, the results documented here add to the literature on hedonic models and index construction in commercial real estate established by Fisher et al (1994) and Geltner and Pollakowski (2007). This is the first paper to simultaneously create hedonic pricing models and indices for six major global office markets employing the same method and model for all of them: London, Paris, Tokyo, Hong Kong, New York and Los Angeles. This allows us to document differences and commonalities in the pricing functions and price developments across these markets. We find a negative relationship between size and the price per square foot of office space in all markets, yet a positive effect of building height. We also find that renovated buildings tend to be relatively expensive.

On the other hand, we find a wide range in the speed of depreciation, varying from almost zero in London to approximately 2.5 percent per year in Tokyo. Location is important, and we generally find statistically and economically significant price effects of location within a CBD. These effects tend to be positive, with the exception of Los Angeles, where office space located in the CBD apparently sells at a discount.

The second main contribution is to the spatial econometric literature in commercial real estate, which hitherto consisted of two studies covering two cities: Singapore Tu et al (2004) and Paris Nappi-Choulet and Maury (2009). Here, our results are clear: the spatial and spatial-temporal terms we add to the model have a statistically significant relation with the price per square foot of office space, but the economic significance of these terms is negligible. Whether we look at their coefficient size, their impact on the coefficients of the other hedonic terms, or their impact on the overall explanatory power of the models, we always find very small effects. So even while there are good theoretical reasons to include spatial elements in hedonic pricing models for office buildings, the empirics suggest that they do not add much value.

Only in some of the office price indices we create on the basis of our valuation models do we find some effects of the inclusion of spatial elements. In these cases, the spatial indices suggest stronger decreases in office prices during the initial years of the Global Financial Crisis.

Given the recent worldwide advances in data collection on metropolitan commercial real estate markets, we expect ongoing development of office price models and indices. In that respect, our paper is just another small step on a long road. 


\section{References}

Anselin L (1988) Spatial Econometrics: Methods and Models. Studies in Operational Regional Science, Springer, Dordrecht

Bokhari S, Geltner D (2011) Loss aversion and anchoring in commercial real estate pricing: Empirical evidence and price index implications. Real Estate Economics 39(4):635-670

Bokhari S, Geltner DM (2014) Characteristics of depreciation in commercial and multi-family property: An investment perspective. Working Paper, MIT Center for Real Estate - Commercial Real Estate Data Laboratory

se Can A, Megbolugbe I (1997) Spatial dependence and house price index construction. The Journal of Real Estate Finance and Economics 14(1-2):203222

Chegut AM, Eichholtz PMA, Kok N (2014) Supply, demand and the value of green buildings. Urban Studies 51(1):22-43

Colwell PF, Munneke HJ, Trefzger JW (1998) Chicago's office market: Price indices, location and time. Real Estate Economics 26(1):83-106

Devaney S, Diaz RM (2011) Transaction based indices for the UK commercial real estate market: an exploration using IPD transaction data. Journal of Property Research 28(4):269-289, DOI 10.1080/09599916.2011.601317, http://www.tandfonline.com/doi/pdf/10.1080/09599916.2011.601317

Downs DH, Slade BA (1999) Characteristics of a full-disclosure, transactionbased index of commercial real estate. Journal of Real Estate Portfolio Management 5(1):95-104

Eichholtz PMA, Kok N, Quigley JM (2010) Doing well by doing good? green office buildings. American Economic Review 100(5):2492-2509

Eichholtz PMA, Kok N, Quigley JM (2013) The economics of green building. Review of Economics and Statistics 95(1):50-63

Elhorst JP, Lacombe DJ, Piras G (2012) On model specification and parameter space definitions in higher order spatial econometric models. Regional Science and Urban Economics 42(1):211-220

Fisher JD, Geltner DM, Webb RB (1994) Value indices of commercial real estate: A comparison of index construction methods. The Journal of Real Estate Finance and Economics 9:137-164

Fisher JD, Geltner DM, Pollakowski HO (2007) A quarterly transactions-based index of institutional real estate investment performance and movements in supply and demand. The Journal of Real Estate Finance and Economics $34(1): 5-33$

Geltner DM, Bokhari S (2008) A technical note on index methodology enhancement by two-stage regression estimation. Tech. rep., MIT Center for Real Estate - Commercial Real Estate Data Laboratory

Geltner DM, Pollakowski HO (2007) A set of indexes for trading commercial real estate based on the real capital analytics transaction prices database. Tech. rep., MIT Center for Real Estate - Commercial Real Estate Data Laboratory 
Kelejian HH, Prucha IR (2010) Specification and estimation of spatial autoregressive models with autoregressive and heteroskedastic disturbances. Journal of Econometrics 157(1):53-67

Kelejian HH, Prucha IR, Yuzefovich Y (2004) Instrumental variable estimation of a spatial autorgressive model with autoregressive disturbances: Large and small sample results. In: Le Sage J, Pace R (eds) Spatial and Spatiotemporal Econometrics, Advances In Econometrics, Vol. 18, Elseviers

Komatsu Y, Shimazu M (2003) Life time estimation of office buildings based on general contractors construction records. Journal of Architecture, Planning \& Environmental Engineering (565):317-322

LeSage JP, Pace RK (2009) Introduction to Spatial Econometrics. Taylor \& Francis Group, Boca Raton

LeSage JP, Pace RK (2010) Spatial econometric models. In: In Handbook of Applied Spatial Analysis, Springer Berlin Heidelberg, pp 355-376

Nappi-Choulet I, Maury TP (2009) A spatiotemporal autoregressive price index for the paris office property market. Real Estate Economics 37(2):305340, DOI 10.1111/j.1540-6229.2009.00244.x

Pace RK, Barry R, Clapp JM, Rodriquez M (1998) Spatiotemporal autoregressive models of neighborhood effects. The Journal of Real Estate Finance and Economics 17(1):15-33

Pace RK, Barry R, Gilley W, Sirmans C (2000) A method for spatial-temporal forecasting with an application to real estate prices. International Journal of Forecasting 16(2):229-246, DOI 10.1016/S0169-2070(99)00047-3

Rosen S (1974) Hedonic prices and implicit markets: Product differentiation in pure competition. Journal of Political Economy 82(1):34-55

Tu Y, Yu SM, Sun H (2004) Transaction-based office price indexes: A spatiotemporal modeling approach. Real Estate Economics 32(2):297-328, DOI 10.1111/j.1080-8620.2004.00093.x 


\section{Tables and Figures}

Table 1: Global Office Market Transaction and Building Statistics (Complete Transactions Greater than US $\$ 10$ Million - 2007 to 2013)

\begin{tabular}{|c|c|c|c|c|c|c|}
\hline & London & Paris & Tokyo & Hong Kong & New York & Los Angeles \\
\hline \multicolumn{7}{|c|}{ Transaction Price - Mean (Std. Dev.) } \\
\hline \multirow[t]{2}{*}{ Transaction price $(\$ \mathrm{mln})$} & 138.40 & 108.70 & 74.20 & 45.20 & 125.20 & 52.47 \\
\hline & $(201.40)$ & $(161.90)$ & $(144.10)$ & $(87.80)$ & $(234.20)$ & $(72.40)$ \\
\hline Log transaction price & 18.16 & 18.01 & 17.45 & 17.08 & 17.78 & 17.28 \\
\hline \multirow[t]{2}{*}{ Price per square foot } & $1,119.45$ & 842.06 & 958.64 & $1,464.67$ & 537.99 & 299.43 \\
\hline & $(761.60)$ & $(496.56)$ & $(682.93)$ & $(779.97)$ & $(500.87)$ & (187.38) \\
\hline \multirow[t]{2}{*}{ Log price per square foot } & 6.82 & 6.58 & 6.67 & 7.16 & 5.95 & 5.55 \\
\hline & $(0.66)$ & $(0.58)$ & $(0.67)$ & $(0.54)$ & $(0.84)$ & $(0.56)$ \\
\hline \multicolumn{7}{|c|}{ Building Features - Mean (Std. Dev.) } \\
\hline \multirow[t]{2}{*}{ Age of building (years) } & 50.41 & 51.87 & 20.74 & 18.89 & 62.45 & 28.66 \\
\hline & $(64.17)$ & $(64.75)$ & $(13.03)$ & $(12.48)$ & $(34.98)$ & $(19.08)$ \\
\hline \multirow[t]{2}{*}{ Size of building (sq. ft. thousands) } & 139.90 & 147.44 & 96.19 & 40.92 & 285.26 & 186.36 \\
\hline & $(178.20)$ & $(176.65)$ & (220.18) & $(84.08)$ & $(387.79)$ & $(217.46)$ \\
\hline \multirow[t]{2}{*}{ Stories of building } & 8.23 & 7.83 & 10.19 & 30.97 & 13.45 & 7.23 \\
\hline & $(5.54)$ & $(6.11)$ & $(6.28)$ & (12.47) & (12.69) & $(8.50)$ \\
\hline \multirow[t]{2}{*}{ Renovated status } & 0.27 & 0.22 & 0.05 & 0.03 & 0.45 & 0.29 \\
\hline & $(0.44)$ & $(0.42)$ & $(0.21)$ & $(0.16)$ & $(0.50)$ & $(0.45)$ \\
\hline \multirow[t]{2}{*}{ Time since renovation (years) } & 2.68 & 1.42 & 0.34 & 0.10 & 6.28 & 3.74 \\
\hline & $(7.07)$ & $(4.01)$ & $(2.47)$ & $(0.70)$ & $(10.06)$ & $(9.98)$ \\
\hline \multicolumn{7}{|l|}{ Investor Type - Percentage } \\
\hline Equity Fund & 0.13 & 0.08 & 0.03 & 0.02 & 0.14 & 0.22 \\
\hline Institutional & 0.41 & 0.49 & 0.15 & 0.04 & 0.12 & 0.13 \\
\hline Private & 0.24 & 0.17 & 0.33 & 0.66 & 0.56 & 0.47 \\
\hline Public & 0.12 & 0.18 & 0.40 & 0.05 & 0.08 & 0.11 \\
\hline Owner occupied & 0.04 & 0.04 & 0.09 & 0.09 & 0.09 & 0.07 \\
\hline Unknown & 0.06 & 0.04 & 0.01 & 0.14 & 0.01 & - \\
\hline \multicolumn{7}{|l|}{ Seller Type - Percentage } \\
\hline Equity Fund & 0.11 & 0.09 & 0.04 & 0.03 & 0.10 & - \\
\hline Institutional & 0.43 & 0.50 & 0.20 & 0.11 & 0.14 & 0.12 \\
\hline Private & 0.19 & 0.09 & 0.36 & 0.54 & 0.54 & 0.21 \\
\hline Public & 0.19 & 0.23 & 0.24 & 0.12 & 0.10 & 0.45 \\
\hline Owner occupied & 0.04 & 0.07 & 0.14 & 0.05 & 0.11 & 0.13 \\
\hline Unknown & 0.04 & 0.02 & 0.03 & 0.13 & 0.02 & 0.02 \\
\hline \multicolumn{7}{|l|}{ Year of Transaction - Percentage } \\
\hline 2007 & 0.15 & 0.11 & 0.14 & 0.20 & 0.26 & 0.27 \\
\hline 2008 & 0.10 & 0.09 & 0.16 & 0.09 & 0.12 & 0.12 \\
\hline 2009 & 0.12 & 0.11 & 0.10 & 0.14 & 0.03 & 0.04 \\
\hline 2010 & 0.13 & 0.16 & 0.14 & 0.18 & 0.10 & 0.08 \\
\hline 2011 & 0.13 & 0.18 & 0.13 & 0.11 & 0.13 & 0.11 \\
\hline 2012 & 0.17 & 0.18 & 0.14 & 0.14 & 0.18 & 0.17 \\
\hline 2013 & 0.21 & 0.17 & 0.19 & 0.15 & 0.18 & 0.21 \\
\hline Number of Transactions & 784 & 492 & 1,316 & 516 & 978 & 656 \\
\hline \multicolumn{7}{|c|}{$\begin{array}{l}\text { Notes: Table } 1 \text { gives the descriptive statistics for the six global property markets in Europe, Asia } \\
\text { and North America for transactions greater than US } \$ 10 \text { million for } 2007 \text { to 2013. The table } \\
\text { documents the mean and standard deviation of transaction prices, building features, investor and } \\
\text { seller types and year of transaction. }\end{array}$} \\
\hline
\end{tabular}


Table 2: Regression Results for European Office Sample - London and Paris Dependent Variable: Log Price per Square Foot (Results Reported in Percentage Points)

\begin{tabular}{|c|c|c|c|c|c|c|}
\hline \multirow[b]{3}{*}{ Variable } & \multicolumn{3}{|c|}{ London } & \multicolumn{3}{|c|}{ Paris } \\
\hline & (1) & (2) & (3) & (4) & (5) & (6) \\
\hline & Hedonic & SARAR & STARAR & Hedonic & SARAR & STARAR \\
\hline \multicolumn{7}{|c|}{ Spatial and Temporal Dependence } \\
\hline \multirow[t]{2}{*}{ Spatial } & - & $\begin{array}{r}0.32^{* * *} \\
(0.07)\end{array}$ & $\begin{array}{r}0.47^{* * * *} \\
(0.08)\end{array}$ & - & $\begin{array}{r}0.26^{* * * *} \\
(0.08)\end{array}$ & $\begin{array}{l}0.18^{*} \\
(0.09)\end{array}$ \\
\hline & $\begin{array}{l}- \\
-\end{array}$ & ${ }^{(0.07)}$ & $\begin{array}{r}(0.08) \\
0.03\end{array}$ & - & $\begin{array}{r}(0.00) \\
-\end{array}$ & $\begin{array}{r}(0.09) \\
-0.73\end{array}$ \\
\hline Temporal & - & - & $(0.28)$ & - & - & $(0.45)$ \\
\hline \multirow{2}{*}{ Space \& Time } & - & - & -0.19 & - & - & -1.95 \\
\hline & - & - & $(1.21)$ & - & - & $(1.78)$ \\
\hline Spatial Error & - & $1.49^{* * *}$ & $\begin{array}{r}1.42^{* * * *} \\
(0.38)\end{array}$ & - & $\begin{array}{l}1.36^{*} \\
(0.72)\end{array}$ & $\begin{array}{l}1.70^{* *} \\
(0.75)\end{array}$ \\
\hline \multicolumn{7}{|l|}{ Hedonics } \\
\hline \multirow[t]{2}{*}{ Log Size } & $-10.53^{* * *}$ & $-10.19^{* * *}$ & $-9.93^{* * *}$ & $-8.52^{* * *}$ & $-6.77^{* *}$ & $-6.75^{* *}$ \\
\hline & $(2.50)$ & $(2.45)$ & $(2.47)$ & $(2.74)$ & $(3.12)$ & $(3.16)$ \\
\hline \multirow[t]{2}{*}{ Age } & -0.07 & -0.10 & -0.13 & -0.15 & $-0.18^{*}$ & $-0.17^{*}$ \\
\hline & $(0.08)$ & $(0.09)$ & $(0.09)$ & $(0.11)$ & $(0.10)$ & $(0.10)$ \\
\hline \multirow{2}{*}{ Age Sq. } & 0.00 & 0.00 & 0.00 & $0.00^{* *}$ & $0.00^{* *}$ & $0.00^{* *}$ \\
\hline & $(0.00)$ & $(0.00)$ & $(0.00)$ & $(0.00)$ & $(0.00)$ & $(0.00)$ \\
\hline \multirow{2}{*}{ Stories } & 0.50 & 0.53 & 0.60 & $0.61^{*}$ & 0.15 & 0.26 \\
\hline & $(0.42)$ & $(0.51)$ & $(0.51)$ & $(0.37)$ & $(0.43)$ & $(0.45)$ \\
\hline \multirow[t]{2}{*}{ Renovated $(=1)$} & 4.77 & 5.15 & 5.09 & $17.78^{* * *}$ & $15.07^{* * *}$ & $15.99^{* * *}$ \\
\hline & $(4.71)$ & $(4.45)$ & $(4.48)$ & $(5.55)$ & (5.33) & $(5.26)$ \\
\hline \multirow[t]{2}{*}{$\operatorname{CBD}(=1)$} & $22.93^{* *}$ & 10.76 & 3.85 & $72.56^{* * *}$ & $63.45^{* * *}$ & $65.49^{* * * *}$ \\
\hline & $(9.08)$ & (11.67) & $(12.13)$ & $(7.88)$ & $(8.75)$ & $(8.97)$ \\
\hline Submarkets & Yes & Yes & Yes & Yes & Yes & Yes \\
\hline \multicolumn{7}{|c|}{ Investor Type (Relative to Owner Occupier) } \\
\hline Equity Fund & $-25.23^{* *}$ & $-28.40^{* * *}$ & $-29.42^{* * *}$ & 18.16 & 14.80 & 14.64 \\
\hline & $(11.09)$ & $(10.60)$ & $(10.72)$ & $(12.88)$ & (11.19) & $(10.59)$ \\
\hline Institution & -7.84 & -11.89 & -14.09 & 18.27 & 15.78 & $16.21^{*}$ \\
\hline & $(10.14)$ & $(9.24)$ & (9.37) & (11.16) & $(9.94)$ & $(9.20)$ \\
\hline Private & $-25.66^{* *}$ & $-29.36^{* * *}$ & $-31.07^{* * *}$ & -6.33 & -6.69 & -7.05 \\
\hline & $(10.45)$ & $(9.75)$ & $(9.92)$ & $(11.62)$ & $(10.80)$ & (10.19) \\
\hline Public & $-36.23^{* * *}$ & $-38.88^{* * *}$ & $-40.04^{* * *}$ & 6.01 & 3.10 & 3.18 \\
\hline & (11.11) & $(10.42)$ & $(10.50)$ & (11.90) & (10.69) & $(10.07)$ \\
\hline Unknown & -7.66 & -9.46 & -10.79 & 1.30 & -1.07 & 1.10 \\
\hline & $(12.52)$ & (11.66) & (11.88) & $(14.82)$ & $(14.26)$ & (14.32) \\
\hline Seller Type (R & ive to $O w$ & er Occupi & & & & \\
\hline Equity Fund & -5.47 & -3.15 & -2.28 & 14.23 & 15.84 & 16.92 \\
\hline & (11.44) & (12.50) & (13.03) & (11.37) & $(12.56)$ & (12.57) \\
\hline Institution & 4.39 & 3.59 & 3.35 & 7.16 & 6.54 & 7.27 \\
\hline & $(10.15)$ & (11.29) & (11.77) & $(9.37)$ & (10.94) & $(11.07)$ \\
\hline Private & -4.00 & -1.42 & -0.87 & 12.21 & 12.20 & 13.12 \\
\hline & $(10.60)$ & (11.60) & (12.12) & $(11.01)$ & $(11.20)$ & (11.39) \\
\hline Public & -10.75 & -9.06 & -8.56 & 10.10 & 9.32 & 9.92 \\
\hline & $(10.74)$ & $(11.85)$ & $(12.34)$ & $(9.94)$ & $(11.55)$ & $(11.63)$ \\
\hline Unknown & $-25.74^{*}$ & -18.50 & -17.30 & 17.18 & 15.88 & 13.55 \\
\hline & (13.77) & (14.79) & $(15.16)$ & $(16.76)$ & $(16.47)$ & $(16.30)$ \\
\hline Years (Relativ & 2007) & & & & & \\
\hline 2008 & $\begin{array}{r}-25.34^{* * * *} \\
(8.00)\end{array}$ & $\begin{array}{r}-38.70^{* * *} \\
(7.79)\end{array}$ & $\begin{array}{r}-43.53^{* * * *} \\
(7.90)\end{array}$ & $\begin{array}{r}7.04 \\
(9.60)\end{array}$ & $\begin{array}{r}1.13 \\
(10.87)\end{array}$ & $\begin{array}{r}3.34 \\
(11.11)\end{array}$ \\
\hline 2009 & $-61.17^{* * * *}$ & $\begin{array}{l}-73.92^{* * *} \\
(7.52)\end{array}$ & $\begin{array}{l}-78.27^{* * * *} \\
(784)\end{array}$ & $-23.89^{* * *}$ & $\begin{array}{l}-31.14^{* * *} \\
(1040)\end{array}$ & $\begin{array}{l}-27.40^{* * *} \\
(10.56)\end{array}$ \\
\hline 2010 & $\begin{array}{r}(7.48) \\
-55.44^{* * *}\end{array}$ & $\begin{array}{r}(7.52) \\
-74.61^{* * *}\end{array}$ & $\begin{array}{r}(7.84) \\
-81.43^{* * * *}\end{array}$ & $\begin{array}{r}(9.14) \\
-24.33^{* * *}\end{array}$ & $\begin{array}{r}(10.40) \\
-34.53^{* * *}\end{array}$ & $\begin{array}{r}(10.56) \\
-28.92^{* * *}\end{array}$ \\
\hline & $(7.32)$ & $(7.83)$ & $(8.40)$ & $(8.51)$ & $(9.61)$ & $(10.00)$ \\
\hline 2011 & $\begin{array}{r}-41.81^{* * * *} \\
(7.16)\end{array}$ & $\begin{array}{r}-60.85^{* * *} \\
(7.70)\end{array}$ & $\begin{array}{r}-67.82^{* * * *} \\
(8,03)\end{array}$ & $\begin{array}{l}-10.95 \\
(8.15)\end{array}$ & $\begin{array}{r}-21.91^{* * *} \\
(9.23)\end{array}$ & $\begin{array}{l}-15.54 \\
(9.83)\end{array}$ \\
\hline 2012 & $\begin{array}{r}(7.16) \\
-48.12^{* * *}\end{array}$ & $\begin{array}{r}(7.70) \\
-70.72^{* * *}\end{array}$ & $\begin{array}{r}(8.03) \\
-78.99^{* * * *}\end{array}$ & $\begin{array}{r}(8.15) \\
-27.10^{* * *}\end{array}$ & $\begin{array}{r}(9.23) \\
-40.54^{* * *}\end{array}$ & $\begin{array}{r}(9.83) \\
-33.00^{* * *}\end{array}$ \\
\hline & $(6.79)$ & $(7.90)$ & $(8.30)$ & $(8.36)$ & $(9.92)$ & (10.67) \\
\hline 2013 & $-37.93^{* * *}$ & $-59.33^{* * *}$ & $-67.83^{* * *}$ & $-17.36^{* *}$ & $-30.45^{* * *}$ & $-23.05^{* *}$ \\
\hline & $(6.47)$ & $(7.54)$ & $(8.41)$ & $(8.22)$ & $(9.62)$ & $(10.52)$ \\
\hline Constant & $830.28^{* * *}$ & $816.27^{* * *}$ & $810.66^{* * *}$ & $717.31^{* * *}$ & $701.22^{* * *}$ & $702.55^{* * *}$ \\
\hline & (33.53) & (33.99) & (34.63) & $(35.83)$ & $(38.99)$ & $(38.94)$ \\
\hline $\operatorname{Adj} .-R^{2}$ & 0.37 & 0. & 0.42 & 0.39 & 1 & 0. \\
\hline No. Obs. & 784 & 784 & 784 & 492 & 492 & 492 \\
\hline
\end{tabular}

Notes: Table 2 documents the results for London and Paris for building assets transacting for US $\$$ 10 million and greater. All results are reported in percentage points, where the coefficient has been pre-multiplied by 100 for ease of interpretation. Results reported are for the hedonic, SARAR and STARAR models specified in equations 1, 3 and 5, respectively for transactions for 2007 to 2013. Investor and seller types are relative to owner occupiers. Buying or selling transaction prices paid are per square foot. Periodic transaction price trends are reported for the 2008 to 2013 period with coefficients reporting the relative average transaction prices since 2007. Sub-market results are available by request. 
Table 3: Regression Results for Asia Office Sample - Tokyo and Hong Kong Dependent Variable: Log Price per Square Foot (Results Reported in Percentage Points)

\begin{tabular}{|c|c|c|c|c|c|c|}
\hline \multirow[b]{3}{*}{ Variable } & \multicolumn{3}{|c|}{ Tokyo } & \multicolumn{3}{|c|}{ Hong Kong } \\
\hline & (1) & (2) & (3) & (4) & (5) & (6) \\
\hline & Hedonic & SARAR & STARAR & Hedonic & SARAR & STARAR \\
\hline \multicolumn{7}{|c|}{ Spatial and Temporal Dependence } \\
\hline \multirow[t]{2}{*}{ Spatial } & - & $\begin{array}{c}0.17^{* *} \\
(0.07)\end{array}$ & $\begin{array}{r}0.30^{* * *} \\
(0.10)\end{array}$ & - & $\begin{array}{r}0.02 \\
(0.02)\end{array}$ & $\begin{array}{r}0.02 \\
(0.02\end{array}$ \\
\hline & - & $(0.07)$ & $(0.10)$ & - & $(0.02)$ & $(0.02)$ \\
\hline \multirow[t]{2}{*}{ Temporal } & - & - & 0.11 & - & - & 0.04 \\
\hline & - & - & $(0.15)$ & - & - & $(0.04)$ \\
\hline \multirow[t]{2}{*}{ Space \& Time } & - & - & 1.29 & - & - & 0.07 \\
\hline & - & & $(0.99)$ & - & - & $(0.15)$ \\
\hline Spatial Error & - & $\begin{array}{r}2.50^{* * * *} \\
(0.30)\end{array}$ & $2.69^{* * * *}$ & - & $\begin{array}{c}0.93^{* *} \\
(0.39)\end{array}$ & $0.82^{* * *}$ \\
\hline \multicolumn{7}{|l|}{ Hedonics } \\
\hline Log Size & $\begin{array}{r}-21.56^{* * *} \\
(2.09)\end{array}$ & $\begin{array}{r}-20.46^{* * *} \\
(2.54)\end{array}$ & $\begin{array}{r}-19.83^{* * *} \\
(2.55)\end{array}$ & $\begin{array}{r}-23.66^{* * *} \\
(2.13)\end{array}$ & $\begin{array}{r}-23.59^{* * *} \\
(3.54)\end{array}$ & $\begin{array}{r}-23.36^{* * *} \\
(3.56)\end{array}$ \\
\hline Age & $\begin{array}{r}-2.58^{* * *} \\
(0.36)\end{array}$ & $\begin{array}{r}-2.45^{* * *} \\
(0.37)\end{array}$ & $\begin{array}{r}-2.46^{* * *} \\
(0.37)\end{array}$ & $\begin{array}{l}-0.44 \\
(0.47)\end{array}$ & $\begin{array}{r}-0.47 \\
(0.53)\end{array}$ & $\begin{array}{c}-0.44 \\
(0.52)\end{array}$ \\
\hline \multirow{2}{*}{ Age Sq. } & $0.04^{* * *}$ & $0.04^{* * *}$ & $0.04^{* * *}$ & 0.01 & 0.01 & 0.01 \\
\hline & $(0.01)$ & $(0.01)$ & $(0.01)$ & $(0.01)$ & $(0.01)$ & $(0.01)$ \\
\hline \multirow{2}{*}{ Stories } & $0.89^{* * *}$ & 0.67 & 0.62 & $1.21^{* * *}$ & $1.21^{* * *}$ & $1.17^{* * *}$ \\
\hline & $(0.32)$ & $(0.47)$ & $(0.46)$ & $(0.17)$ & $(0.18)$ & $(0.19)$ \\
\hline \multirow{2}{*}{ Renovated $(=1)$} & $22.35^{* * *}$ & $23.74^{* * *}$ & $24.23^{* * *}$ & 14.78 & 14.03 & 13.86 \\
\hline & $(7.67)$ & $(6.53)$ & $(6.67)$ & $(10.53)$ & $(14.88)$ & $(14.86)$ \\
\hline \multirow[t]{2}{*}{$\operatorname{CBD}(=1)$} & $20.01^{*}$ & $16.09^{* *}$ & 12.35 & $65.56^{* * *}$ & $63.18^{* * *}$ & $62.63^{* * *}$ \\
\hline & $(10.68)$ & $(7.82)$ & $(8.09)$ & $(10.18)$ & $(11.67)$ & $(11.86)$ \\
\hline Submarkets & Yes & Yes & Yes & Yes & Yes & Yes \\
\hline \multicolumn{7}{|c|}{ Investor Type (Relative to Owner Occupier) } \\
\hline \multirow[t]{2}{*}{ Equity Fund } & 7.21 & 8.60 & 9.08 & 12.95 & 12.78 & 13.10 \\
\hline & $(10.63)$ & $(8.05)$ & $(8.11)$ & $(12.27)$ & $(8.87)$ & $(8.97)$ \\
\hline Institution & $12.02^{*}$ & $12.38^{*}$ & $12.72^{*}$ & -1.51 & -1.18 & -1.49 \\
\hline & (7.13) & $(6.69)$ & $(6.71)$ & $(9.55)$ & $(10.26)$ & $(10.26)$ \\
\hline Private & $\begin{array}{l}-1.18 \\
(6.31\end{array}$ & $\begin{array}{l}-0.25 \\
(5.97)\end{array}$ & $\begin{array}{r}0.04 \\
(6.00)\end{array}$ & $\begin{array}{l}-1.10 \\
(5.966\end{array}$ & $\begin{array}{l}-1.48 \\
(6.87)\end{array}$ & $\begin{array}{l}-1.32 \\
(6.89)\end{array}$ \\
\hline Public & $14.24^{* *}$ & $15.32^{* *}$ & $15.20^{* *}$ & 13.48 & 13.86 & $\begin{array}{r}(6.89) \\
13.84\end{array}$ \\
\hline & $(6.23)$ & $(6.27)$ & $(6.28)$ & $(9.75)$ & (13.35) & (13.39) \\
\hline Unknown & 1.36 & 1.97 & 0.93 & 7.72 & 8.40 & 8.10 \\
\hline & $(15.40)$ & (12.08) & (11.96) & $(7.59)$ & $(8.56)$ & $(8.58)$ \\
\hline Seller Type (R & ive to $\mathrm{Ow}$ & er Occupi & & & & \\
\hline Equity Fund & $\begin{array}{r}15.43 \\
(9.76)\end{array}$ & $\begin{array}{r}13.63^{*} \\
(7.85)\end{array}$ & $\begin{array}{r}13.45^{*} \\
(7.78)\end{array}$ & $\begin{array}{r}-3.18 \\
(11.09)\end{array}$ & $\begin{array}{r}-3.21 \\
(15.34)\end{array}$ & $\begin{array}{r}-3.19 \\
(15.28)\end{array}$ \\
\hline Institution & 7.85 & $9.25^{*}$ & $9.40^{*}$ & 2.30 & 2.74 & 2.56 \\
\hline & $(5.72)$ & $(5.34)$ & $(5.34)$ & $(8.43)$ & $(8.38)$ & $(8.30)$ \\
\hline Private & $\begin{array}{r}-8.32 \\
(5.25)\end{array}$ & $\begin{array}{r}-7.90 \\
(4.91)\end{array}$ & $\begin{array}{r}-7.77 \\
(4.92)\end{array}$ & $\begin{array}{r}-8.87 \\
(7.29)\end{array}$ & $\begin{array}{r}-8.48 \\
(7.83)\end{array}$ & $\begin{array}{r}-8.59 \\
(7.77)\end{array}$ \\
\hline Public & -0.70 & 0.37 & 0.47 & $17.01^{* *}$ & $17.73^{* *}$ & $17.40^{* *}$ \\
\hline & $(5.60)$ & $(5.14)$ & (5.15) & $(8.59)$ & $(8.77)$ & $(8.71)$ \\
\hline Unknown & $-25.04^{* *}$ & -22.57 & -22.22 & -4.22 & -4.17 & -4.34 \\
\hline & $(11.05)$ & $(14.65)$ & $(14.51)$ & $(8.68)$ & $(9.72)$ & (9.65) \\
\hline Years (Relativ & 2007) & & & & & \\
\hline 2008 & $\begin{array}{r}4.96 \\
(5.81)\end{array}$ & $\begin{array}{r}0.43 \\
(6.04)\end{array}$ & $\begin{array}{r}-4.68 \\
(6.42)\end{array}$ & $\begin{array}{r}24.22^{* * * *} \\
(6.66)\end{array}$ & $21.58^{* * *}$ & $\begin{array}{r}21.93^{* * *} \\
(7.24)\end{array}$ \\
\hline 2009 & $\begin{array}{r}(5.81) \\
1.70\end{array}$ & $\begin{array}{l}0.04) \\
-4.53\end{array}$ & $\begin{array}{r}(6.42) \\
-10.92\end{array}$ & $\begin{array}{r}(0.00) \\
5.34\end{array}$ & $\begin{array}{r}(7.25) \\
3.02\end{array}$ & 2.81 \\
\hline & (6.79) & $(7.02)$ & $(7.50)$ & $(5.66)$ & $(5.81)$ & $(5.81)$ \\
\hline 2010 & -4.32 & $-11.92^{*}$ & $-18.85^{* *}$ & $29.93^{* * *}$ & $28.28^{* * *}$ & $27.74^{* * *}$ \\
\hline & $(6.16)$ & $(6.97)$ & $(7.65)$ & $(5.32)$ & $(5.85)$ & (5.93) \\
\hline 2011 & $\begin{array}{r}3.10 \\
(6.32)\end{array}$ & $\begin{array}{r}-3.54 \\
(7.88)\end{array}$ & $\begin{array}{r}-9.99 \\
(8.76)\end{array}$ & $\begin{array}{r}41.64^{* * * *} \\
(6.44)\end{array}$ & $\begin{array}{l}39.57^{* * * *} \\
(5.84)\end{array}$ & $\begin{array}{r}38.99^{* * *} \\
(5.96)\end{array}$ \\
\hline & $\begin{array}{r}(6.32) \\
-14.96 * *\end{array}$ & $\begin{array}{r}(7.88) \\
-23.32^{* * *}\end{array}$ & $\begin{array}{r}(8.76) \\
-30.59^{* * *}\end{array}$ & $\begin{array}{r}(6.44) \\
54.53^{* * * *}\end{array}$ & $\begin{array}{r}(5.84) \\
53.35^{* * *}\end{array}$ & $\begin{array}{r}(5.96) \\
52.98^{* * * *}\end{array}$ \\
\hline 2012 & $\begin{array}{r}-14.96 \% \\
(6.16)\end{array}$ & $\begin{array}{r}-23.32 \\
(8.91)\end{array}$ & $\begin{array}{r}-30.59 .7 \\
(9.87)\end{array}$ & $\begin{array}{r}(6.04) \\
\quad(53.04\end{array}$ & $\begin{array}{l}53.83 \\
(6.95)\end{array}$ & $\begin{array}{r}(7.14) \\
\quad 2.98\end{array}$ \\
\hline 2013 & $-19.24^{* * *}$ & $-28.65^{* * *}$ & $-37.15^{* * *}$ & $69.09^{* * *}$ & $65.53^{* * *}$ & $65.76^{* * *}$ \\
\hline & $(5.72)$ & $(7.57)$ & $(8.75)$ & $(6.07)$ & $(6.33)$ & $(6.72)$ \\
\hline Constant & $907.74^{* * *}$ & $890.37^{* * *}$ & $878.32^{* * *}$ & $845.51^{* * *}$ & $844.65^{* * *}$ & $842.48^{* * *}$ \\
\hline & $(25.04)$ & $(27.68)$ & $(28.21)$ & $(25.68)$ & $(35.67)$ & $(36.14)$ \\
\hline $\operatorname{Adj} .-R^{2}$ & & & & 0.57 & 0.57 & 57 \\
\hline No. Obs. & 1,316 & 1,316 & 1,316 & 516 & 516 & 516 \\
\hline
\end{tabular}

Notes: Table 3 documents the results for Tokyo and Hong Kong for buildings transacting for US $\$ 10$ million and greater. Similar to the European results, all results are reported in percentage points, where the coefficient has been pre-multiplied by 100 for ease of interpretation. Results reported are for the hedonic, SARAR and STARAR models specified in equations 1,3 and 5 , respectively for transactions over the 2007 to 2013 period. Investor and seller types are relative to owner occupiers, buying or selling transaction prices paid or received per square foot. Periodic transaction price trends are reported for the 2008 to 2013 period with coefficients reporting the relative average transaction prices since 2007 . 
Table 4: Regression results for North American Office Sample - New York City and Los Angeles

Dependent Variable: Log Price per Square Foot (Results Reported in Percentage Points)

\begin{tabular}{|c|c|c|c|c|c|c|}
\hline \multirow[b]{3}{*}{ Variable } & \multicolumn{3}{|c|}{ New York City } & \multicolumn{3}{|c|}{ Los Angeles } \\
\hline & (1) & (2) & (3) & (4) & (5) & (6) \\
\hline & Hedonic & SARAR & STARAR & Hedonic & SARAR & STARAR \\
\hline \multicolumn{7}{|c|}{ Spatial and Temporal Dependence } \\
\hline \multirow[t]{2}{*}{ Spatial } & - & $0.22^{* * *}$ & $0.26^{* * *}$ & - & -0.14 & -0.03 \\
\hline & - & $(0.08)$ & $(0.08)$ & - & $(0.10)$ & $(0.11)$ \\
\hline \multirow[t]{2}{*}{ Temporal } & - & & -0.01 & - & - & -0.02 \\
\hline & - & - & $(0.29)$ & - & - & $(0.32)$ \\
\hline \multirow[t]{2}{*}{ Space \& Time } & - & - & $2.38^{*}$ & - & - & 1.12 \\
\hline & - & & $(1.35)$ & - & - & $(0.75)$ \\
\hline \multirow[t]{2}{*}{ Spatial Error } & - & $2.29^{* * *}$ & $2.20^{* * * *}$ & - & 0.30 & 0.03 \\
\hline & - & $(0.28)$ & $(0.30)$ & - & $(1.31)$ & $(1.33)$ \\
\hline \multicolumn{7}{|l|}{ Hedonics } \\
\hline Log Size & $\begin{array}{r}-34.38^{* * *} \\
(2.10)\end{array}$ & $\begin{array}{r}-31.94^{* * *} \\
(2.38)\end{array}$ & $\begin{array}{r}-32.05^{* * * *} \\
(2.37)\end{array}$ & $\begin{array}{r}-21.78^{* * *} \\
(3.12)\end{array}$ & $\begin{array}{r}-22.34^{* * *} \\
(3.29)\end{array}$ & $\begin{array}{r}-21.92^{* * *} \\
(3.33)\end{array}$ \\
\hline \multirow[t]{2}{*}{ Age } & $-0.88^{* * *}$ & $-0.97^{* * * *}$ & $-0.98^{* * *}$ & $-1.59^{* * *}$ & $-1.57^{* * * *}$ & $-1.60^{* * * *}$ \\
\hline & $(0.23)$ & $(0.25)$ & $(0.25)$ & $(0.32)$ & $(0.32)$ & $(0.33)$ \\
\hline Age Sq. & $\begin{array}{r}0.00^{* * *} \\
(0.00)\end{array}$ & $\begin{array}{r}0.01^{* * * *} \\
(0.00)\end{array}$ & $\begin{array}{r}0.01^{* * *} \\
(0.00)\end{array}$ & $0.01^{* * *}$ & $\begin{array}{r}0.01^{* * * *} \\
(0.00)\end{array}$ & $0.01^{* * *}$ \\
\hline \multirow{2}{*}{ Stories } & $0.94^{* * *}$ & ${ }_{0.53^{*}}^{(0.00)}$ & $\begin{array}{l}(0.00) \\
0.55^{*}\end{array}$ & $1.65^{* * *}$ & $1.80^{* * *}$ & $\begin{array}{r}(0.00) \\
1.69^{* * *}\end{array}$ \\
\hline & $(0.23)$ & $(0.31)$ & $(0.31)$ & $(0.34)$ & $(0.41)$ & $(0.42)$ \\
\hline \multirow[t]{2}{*}{ Renovated $(=1)$} & $17.40^{* * * *}$ & $16.49^{* * *}$ & $16.03^{* * *}$ & 2.41 & 2.05 & 2.34 \\
\hline & $(4.31)$ & $(3.98)$ & $(4.00)$ & $(4.33)$ & $(4.25)$ & $(4.27)$ \\
\hline \multirow[t]{2}{*}{$\operatorname{CBD}(=1)$} & $76.57^{* * *}$ & $65.03^{* * *}$ & $61.40^{* * *}$ & $-55.83^{* * *}$ & $-52.85^{* * *}$ & $-55.16^{* * *}$ \\
\hline & $(9.93)$ & $(11.89)$ & $(11.90)$ & $(8.91)$ & $(10.51)$ & $(10.68)$ \\
\hline Submarkets & Yes & Yes & Yes & Yes & Yes & Yes \\
\hline \multicolumn{7}{|c|}{ Investor Type (Relative to Owner Occupier) } \\
\hline Equity Fund & $\begin{array}{r}24.88^{* * * *} \\
(8.56)\end{array}$ & $\begin{array}{r}19.20^{* *} \\
(8.66)\end{array}$ & $\begin{array}{r}20.03^{* *} \\
(8.64)\end{array}$ & $\begin{array}{r}-3.97 \\
(8.04)\end{array}$ & $\begin{array}{r}-4.07 \\
(7.38)\end{array}$ & $\begin{array}{r}-4.04 \\
(7.32)\end{array}$ \\
\hline Institution & $28.37^{* * * *}$ & $22.84^{* *}$ & $23.22^{* *}$ & $\begin{array}{l}0.077 \\
-7.62\end{array}$ & -7.12 & -7.57 \\
\hline & $(8.75)$ & $(9.17)$ & $(9.08)$ & $(8.51)$ & $(8.37)$ & $(8.46)$ \\
\hline Private & 11.38 & 8.63 & 7.60 & -7.36 & -7.42 & -7.28 \\
\hline & $(7.05)$ & $(7.30)$ & $(7.29)$ & (7.19) & $(6.30)$ & $(6.30)$ \\
\hline Public & $36.22^{* * *}$ & $35.85^{* * *}$ & $34.73^{* * *}$ & 10.31 & 9.84 & 9.90 \\
\hline & $(9.53)$ & $(9.78)$ & $(9.80)$ & $(8.74)$ & $(7.97)$ & $(8.00)$ \\
\hline Unknown & $60.77^{* * *}$ & $50.52^{* * *}$ & $49.80^{* * *}$ & 36.28 & 35.50 & 35.61 \\
\hline & $(23.39)$ & $(12.91)$ & $(12.69)$ & (53.39) & $(25.24)$ & $(25.00)$ \\
\hline Seller Type (R & ive to $\mathrm{Ow}$ & er Occupie & & & & \\
\hline Equity Fund & 8.07 & $\begin{array}{r}7.35 \\
(9.27)\end{array}$ & $\begin{array}{r}7.02 \\
(9.27)\end{array}$ & $\begin{array}{l}-19.54 \\
(30.08)\end{array}$ & $\begin{array}{l}-20.45 \\
(28.48)\end{array}$ & $\begin{array}{l}-19.19 \\
(27.47)\end{array}$ \\
\hline Institution & $\begin{array}{r}(8.64) \\
-0.91\end{array}$ & $\begin{array}{r}(9.27) \\
-0.86\end{array}$ & $\begin{array}{r}(9.27) \\
-1.98\end{array}$ & $\begin{array}{r}30.08) \\
2.95\end{array}$ & $\begin{array}{r}(28.48) \\
4.40\end{array}$ & $\begin{array}{l}7.47) \\
3.28\end{array}$ \\
\hline & $(8.01)$ & $(8.21)$ & $(8.27)$ & $(6.57)$ & $(7.26)$ & $(7.38)$ \\
\hline Private & $-12.76^{* *}$ & $-10.85^{*}$ & $-11.07^{*}$ & $-9.34^{*}$ & $-8.92^{*}$ & $-9.16^{*}$ \\
\hline & $(6.46)$ & $(6.57)$ & $(6.63)$ & $(5.63)$ & $(5.30)$ & $(5.33)$ \\
\hline Public & 7.04 & 6.30 & 2.29 & $-9.54^{*}$ & $-8.92^{*}$ & $-9.17^{*}$ \\
\hline & $(8.73)$ & $(8.99)$ & $(9.22)$ & $(5.08)$ & $(5.05)$ & $(5.07)$ \\
\hline Unknown & $-49.55^{* * *}$ & $-40.26^{* * *}$ & $-41.74^{* * * *}$ & 0.29 & 0.52 & 0.84 \\
\hline & $(16.45)$ & (12.86) & (12.75) & (15.14) & $(12.83)$ & $(12.92)$ \\
\hline Years (Relativ & 2007) & & & & & \\
\hline 2008 & $\begin{array}{r}-0.15 \\
(6.77)\end{array}$ & $\begin{array}{r}-3.74 \\
(6.49)\end{array}$ & $\begin{array}{r}-1.00 \\
(6.60)\end{array}$ & $\begin{array}{r}-17.62^{* * * *} \\
(6.27)\end{array}$ & $\begin{array}{r}-15.81^{* * * *} \\
(5.92)\end{array}$ & $\begin{array}{r}-17.15^{* * *} \\
(5.80)\end{array}$ \\
\hline 2009 & $-38.85^{* * *}$ & $\begin{array}{r}-43.26^{* * *} \\
(11.14)\end{array}$ & $\begin{array}{r}-40.04^{* * * *} \\
(11.43)\end{array}$ & $\begin{array}{r}-59.99^{* * * *} \\
(9.04)\end{array}$ & $\begin{array}{l}-58.19^{* * * *} \\
(6.75)\end{array}$ & $-60.05^{* * *}$ \\
\hline 2010 & $\begin{array}{r}(11.04) \\
-32.97^{* * * *}\end{array}$ & $\begin{array}{r}(11.14) \\
-40.18^{* * * *}\end{array}$ & $\begin{array}{r}(11.43) \\
-37.55^{* * * *}\end{array}$ & $\begin{array}{r}(9.04) \\
-39.56^{* * * *}\end{array}$ & $\begin{array}{r}(6.75) \\
-36.77^{* * *}\end{array}$ & $\begin{array}{r}(7.09) \\
-39.25^{* * *}\end{array}$ \\
\hline & $(7.23)$ & $(7.25)$ & (7.41) & $(7.55)$ & $(7.04)$ & $(7.26)$ \\
\hline 2011 & $-36.05^{* * *}$ & $-38.71^{* * *}$ & $-36.28^{* * * *}$ & $-26.44^{* * *}$ & $-23.27^{* * *}$ & $-25.64^{* * *}$ \\
\hline & $(6.51)$ & $(6.16)$ & $(6.32)$ & $(6.46)$ & $(5.65)$ & $(5.71)$ \\
\hline 2012 & $-21.56^{* * *}$ & $-27.81^{* * *}$ & $-26.23^{* * *}$ & $-38.28^{* * *}$ & $-34.66^{* * *}$ & $-38.65^{* * *}$ \\
\hline & $(5.87)$ & $(6.47)$ & $(6.58)$ & $(5.85)$ & $(7.05)$ & $(7.31)$ \\
\hline 2013 & $-13.03^{* *}$ & $\begin{array}{r}-20.43^{* * *} \\
(6.47)\end{array}$ & $-18.85^{* * * *}$ & $\begin{array}{r}-21.41^{* * *} \\
(5.25)\end{array}$ & $\begin{array}{r}-17.74^{* * *} \\
(5.18)\end{array}$ & $\begin{array}{r}-21.15^{* * *} \\
(5.12)\end{array}$ \\
\hline Constant & $\begin{array}{r}(5.95) \\
967.91^{* * * *}\end{array}$ & $\begin{array}{r}(6.47) \\
940.35^{* * *}\end{array}$ & $\begin{array}{r}(6.67) \\
940.16^{* * * *}\end{array}$ & $\begin{array}{r}(5.25) \\
820.65^{* * * *}\end{array}$ & $\begin{array}{r}(5.18) \\
826.16^{* * * *}\end{array}$ & $\begin{array}{r}(5.12) \\
821.25^{* * *}\end{array}$ \\
\hline & $(26.82)$ & $(29.88)$ & $(29.57)$ & $(40.92)$ & $(40.41)$ & $(40.79)$ \\
\hline $\operatorname{Adj} .-R^{2}$ & 0.52 & 0.54 & 0.55 & 0.46 & 0.46 & 0.46 \\
\hline No. Obs. & 978 & 978 & 978 & 656 & 656 & 656 \\
\hline
\end{tabular}

Notes: Table 4 documents the results for New York City and Los Angeles for buildings transacting for US $\$ 10$ million and greater. Similar to the European and Asian results, all results are reported in percentage points, where the coefficient has been pre-multiplied by 100 for ease of interpretation. Results reported are for the hedonic, SARAR and STARAR models specified in equations 1,3 and 5, respectively for transactions over the 2007 to 2013 period. Investor and seller types are relative to owner occupiers. Buying or selling transaction prices are per square foot. Periodic transaction price trends are reported for the 2008 to 2013 period with coefficients reporting the relative average transaction prices since 2007 . 
Table 5: Regression Results for Central Business Districts - London, Tokyo and New York City

Dependent Variable: Log Price per Square Foot (Results Reported in Percentage Points)

\begin{tabular}{|c|c|c|c|c|c|c|c|c|c|}
\hline \multirow[b]{2}{*}{ Variable } & \multicolumn{3}{|c|}{$\begin{array}{c}\text { London } \\
(2)\end{array}$} & \multicolumn{3}{|c|}{ Tokyo } & \multicolumn{3}{|c|}{ New York City } \\
\hline & Hedonic & SARAR & STARAR & Hedonic & SARAR & STARAR & Hedonic & SARAR & STARAR \\
\hline \multicolumn{10}{|c|}{ Spatial and Temporal Dependence } \\
\hline \multirow[t]{2}{*}{ Spatial } & - & 0.08 & 0.09 & - & 0.11 & $0.25^{* *}$ & - & $0.29^{* * *}$ & $0.33^{* * *}$ \\
\hline & - & $(0.10)$ & $(0.11)$ & - & $(0.08)$ & $(0.11)$ & - & $(0.08)$ & $(0.08)$ \\
\hline \multirow[t]{2}{*}{ Temporal } & - & - & -0.32 & - & - & 0.01 & - & - & -0.42 \\
\hline & - & - & $(0.64)$ & - & - & $(0.29)$ & - & - & $(0.38)$ \\
\hline \multirow[t]{2}{*}{ Space \& Time } & - & - & 0.09 & - & - & $2.72^{* * *}$ & - & - & 2.48 \\
\hline & - & - & $(0.86)$ & - & - & $(1.05)$ & - & - & (1.58) \\
\hline \multirow[t]{2}{*}{ Spatial Error } & - & 0.53 & 0.44 & - & $2.56^{* * *}$ & $2.61^{* * *}$ & - & $1.96^{* * *}$ & $1.71^{* * *}$ \\
\hline & - & $(0.68)$ & $(0.68)$ & - & $(0.36)$ & $(0.37)$ & - & $(0.32)$ & $(0.35)$ \\
\hline \multicolumn{10}{|l|}{ Hedonics } \\
\hline Size & $\begin{array}{r}-0.26 \\
(3.23)\end{array}$ & $\begin{array}{c}-0.02 \\
(3.03)\end{array}$ & $\begin{array}{r}0.05 \\
(3.06)\end{array}$ & $\begin{array}{r}-23.67^{* * *} \\
(2.36)\end{array}$ & $\begin{array}{r}-22.63^{* * *} \\
(3.22)\end{array}$ & $\begin{array}{r}-22.22^{* * *} \\
(3.20)\end{array}$ & $\begin{array}{r}-33.31^{* * *} \\
(2.38)\end{array}$ & $\begin{array}{r}-30.83^{* * *} \\
(2.73)\end{array}$ & $\begin{array}{r}-30.78^{* * *} \\
(2.73)\end{array}$ \\
\hline \multirow[t]{2}{*}{ Age } & $-0.35^{* * *}$ & $-0.34^{* * *}$ & $-0.35^{* * *}$ & $-2.54^{* * *}$ & $-2.38^{* * *}$ & $-2.37^{* * *}$ & $-0.80^{* * *}$ & $-0.96^{* * *}$ & $-0.93^{* * *}$ \\
\hline & $(0.10)$ & $(0.10)$ & $(0.10)$ & $(0.41)$ & $(0.45)$ & $(0.44)$ & $(0.27)$ & $(0.25)$ & $(0.25)$ \\
\hline \multirow{2}{*}{ Age Sq. } & $0.00^{* * *}$ & $0.00^{* *}$ & $0.00^{* *}$ & $0.04^{* * *}$ & $0.04^{* * *}$ & $0.04^{* * *}$ & $0.00^{* *}$ & $0.00^{* * *}$ & $0.00^{* * * *}$ \\
\hline & $(0.00)$ & $(0.00)$ & $(0.00)$ & $(0.01)$ & $(0.01)$ & $(0.01)$ & $(0.00)$ & $(0.00)$ & $(0.00)$ \\
\hline \multirow[t]{2}{*}{ Stories } & -0.35 & -0.34 & -0.33 & $2.09^{* * *}$ & $1.83^{* * *}$ & $1.77^{* * * *}$ & $1.07^{* * * *}$ & 0.56 & 0.51 \\
\hline & $\begin{array}{r}(0.53) \\
13.20^{* * *}\end{array}$ & $\begin{array}{r}(0.71) \\
13.38^{* *}\end{array}$ & $\begin{array}{r}(0.71) \\
13.63^{* *}\end{array}$ & $\begin{array}{r}(0.36) \\
18.53^{* *}\end{array}$ & $\begin{array}{r}(0.40) \\
20.38^{* * * *}\end{array}$ & $\begin{array}{r}(0.38) \\
20.32^{* *}\end{array}$ & $\begin{array}{r}(0.25) \\
20.49^{* * * *}\end{array}$ & $\begin{array}{r}(0.34) \\
19.40^{* * *}\end{array}$ & $\begin{array}{r}(0.33) \\
18.99^{* * *}\end{array}$ \\
\hline Renovated $(=1)$ & $\begin{array}{r}13.20^{* *} \\
(5.89)\end{array}$ & $\begin{array}{r}13.38^{* *} \\
(5.91)\end{array}$ & $\begin{array}{r}13.63^{* *} \\
(5.93)\end{array}$ & $\begin{array}{r}18.53^{* * *} \\
(8.55)\end{array}$ & $\begin{array}{r}20.38^{* * * *} \\
(7.80)\end{array}$ & $\begin{array}{r}20.32^{* * *} \\
(7.90)\end{array}$ & $\begin{array}{r}20.49^{* * * *} \\
(4.95)\end{array}$ & $\begin{array}{r}19.40^{* * * *} \\
(4.33)\end{array}$ & $\begin{array}{r}18.99^{* * *} \\
(4.37)\end{array}$ \\
\hline Submarkets & Yes & Yes & Yes & Yes & Yes & Yes & Yes & Yes & Yes \\
\hline Investor Type & lative to $\mathrm{C}$ & wner Occup & jier) & & & & & & \\
\hline Equity Fund & $-40.83^{* * *}$ & $-40.50^{* * *}$ & $-41.03^{* * *}$ & 18.09 & $18.18^{*}$ & $17.90^{*}$ & $21.06^{* *}$ & 16.19 & $17.57^{*}$ \\
\hline & $(15.07)$ & $(14.68)$ & $(14.78)$ & $(13.04)$ & $(10.29)$ & $(10.54)$ & $(10.08)$ & $(10.08)$ & $(10.09)$ \\
\hline Institution & $\begin{array}{l}-11.59 \\
(14.29)\end{array}$ & $\begin{array}{l}-11.04 \\
(13.53\end{array}$ & $\begin{array}{r}-11.47 \\
(13.58\end{array}$ & 10.67 & 11.35 & 10.03 & $\begin{array}{r}26.91^{* *} \\
(10.56)\end{array}$ & $20.07^{*}$ & $21.21^{*}$ \\
\hline & $(14.29)$ & $(13.53)$ & $(13.58)$ & $\begin{array}{r}(8.64) \\
1.87\end{array}$ & $\begin{array}{r}(8.63) \\
2.62\end{array}$ & $\begin{array}{r}(8.62) \\
1.32\end{array}$ & $\begin{array}{r}(10.56) \\
9.86\end{array}$ & $\begin{array}{r}(10.95) \\
7.15\end{array}$ & $\begin{array}{r}(10.83) \\
6.73\end{array}$ \\
\hline Private & $\begin{array}{r}-29.18^{* *} \\
(14.67)\end{array}$ & $\begin{array}{r}-28.84^{* *} \\
(13.87)\end{array}$ & $\begin{array}{r}-28.98^{* *} \\
(13.99)\end{array}$ & $\begin{array}{r}1.87 \\
(7.52)\end{array}$ & $\begin{array}{r}2.62 \\
(7.67)\end{array}$ & $\begin{array}{r}1.32 \\
(7.72)\end{array}$ & $\begin{array}{r}9.86 \\
(8.46)\end{array}$ & $\begin{array}{r}7.15 \\
(8.67)\end{array}$ & $\begin{array}{r}6.73 \\
(8.68)\end{array}$ \\
\hline Public & $-41.27^{* * * *}$ & $-40.65^{* *}$ & $-41.02^{* *}$ & $14.57^{*}$ & $16.01^{* *}$ & $14.67^{*}$ & $35.49^{* * * *}$ & $35.61^{* * * *}$ & $34.16^{* * *}$ \\
\hline & (15.75) & $(16.09)$ & $(16.12)$ & $(7.65)$ & $(8.03)$ & $(8.06)$ & (11.19) & $(11.96)$ & $(12.00)$ \\
\hline Unknown & -22.50 & -21.78 & -21.92 & -29.48 & $-26.19^{*}$ & $-28.49^{*}$ & 39.30 & 30.30 & 29.62 \\
\hline & $(17.04)$ & $(15.00)$ & $(15.15)$ & $(20.26)$ & (15.14) & $(15.13)$ & $(30.83)$ & $(19.80)$ & $(18.38)$ \\
\hline Seller Type (F & ive to $\mathrm{Ow}$ & er Occupier & & & & & & & \\
\hline Equity Fund & 5.71 & 5.05 & 5.47 & 8.20 & 6.39 & 6.09 & 6.34 & 5.45 & 6.12 \\
\hline & (16.78) & (13.78) & (13.35) & $(10.52)$ & $(9.25)$ & $(9.06)$ & $(9.73)$ & $(9.58)$ & $(9.55)$ \\
\hline Institution & 14.00 & 12.55 & 12.38 & 7.78 & 8.79 & 8.93 & 5.08 & 5.54 & 5.13 \\
\hline & $(15.74)$ & $(12.16)$ & (11.99) & $(7.01)$ & $(6.54)$ & $(6.55)$ & $(9.61)$ & $(9.12)$ & $(9.19)$ \\
\hline Private & 6.17 & 5.38 & 5.24 & $-12.56^{* *}$ & $-12.80^{* *}$ & $-12.91^{* *}$ & $-15.86^{* *}$ & $-14.39^{* *}$ & $-14.47^{* *}$ \\
\hline & $(16.12)$ & (12.41) & (12.10) & $(6.27)$ & $(5.73)$ & $(5.75)$ & $(7.41)$ & $(6.83)$ & $(6.91)$ \\
\hline Public & 3.72 & 3.03 & 2.98 & -2.36 & -2.35 & -2.05 & 3.31 & 3.09 & $\begin{array}{l}-2.30 \\
\end{array}$ \\
\hline & (16.53) & (13.34) & (13.03) & $(6.77)$ & $(6.13)$ & (6.14) & (11.15) & $(10.86)$ & (10.95) \\
\hline Unknown & -5.68 & $\begin{array}{l}-6.92 \\
-1\end{array}$ & -7.04 & -6.09 & -2.67 & -2.57 & $-49.50^{* * * *}$ & $-39.01^{* *}$ & $-41.33^{* * *}$ \\
\hline & (21.45) & (14.55) & (14.38) & (14.07) & (11.51) & (11.35) & $(18.55)$ & $(15.37)$ & $(15.12)$ \\
\hline Years (Rela & 2007) & & & & & & & & \\
\hline 2008 & $-25.44^{* *}$ & $-28.30^{* * *}$ & $-29.62^{* * *}$ & 4.76 & 2.47 & -1.94 & -1.37 & -7.41 & -4.98 \\
\hline & $(10.19)$ & $(10.00)$ & (10.38) & $(7.51)$ & $(8.16)$ & (8.59) & $(8.02)$ & $(8.17)$ & (8.59) \\
\hline 2009 & $-80.80^{* * * *}$ & $-83.40^{* * *}$ & $-83.62^{* * *}$ & 0.06 & -3.96 & -10.20 & $-42.24^{* * * *}$ & $-51.03^{* * *}$ & $-49.44^{* * *}$ \\
\hline & $(9.02)$ & (9.27) & $(9.66)$ & $(8.15)$ & $(9.45)$ & $(9.88)$ & (13.30) & (12.99) & (13.49) \\
\hline 2010 & $-54.52^{* * *}$ & $-59.40^{* * *}$ & $-59.38^{* * *}$ & 1.59 & -1.74 & -7.55 & $-31.58^{* * *}$ & $-45.18^{* * *}$ & $-42.33^{* * *}$ \\
\hline & $(8.87)$ & (10.04) & (10.67) & $(7.74)$ & $(9.70)$ & (10.42) & $(8.27)$ & (7.95) & $(8.57)$ \\
\hline 2011 & $-42.53^{* * *}$ & $-48.48^{* * *}$ & $-48.81^{* * *}$ & 4.28 & 1.18 & -5.76 & $-32.18^{* * * *}$ & $-39.89^{* * *}$ & $-36.74^{* * *}$ \\
\hline & (8.39) & (10.16) & $(10.63)$ & (7.79) & $\begin{array}{l}(9.91) \\
\text { (1) }\end{array}$ & (10.91) & $(7.60)$ & (7.31) & $(8.00)$ \\
\hline 2012 & $-47.30^{* * *}$ & $-53.33^{* * *}$ & $-53.11^{* * *}$ & -11.74 & $-18.18^{*}$ & $-25.65^{* *}$ & $-20.11^{* * * *}$ & $-31.25^{* * *}$ & $-27.39^{* * *}$ \\
\hline & $(8.12)$ & (10.45) & (11.32) & $(7.67)$ & $(10.00)$ & $(11.28)$ & $(6.80)$ & (7.39) & $(7.76)$ \\
\hline 2013 & $-51.93^{* * *}$ & $-57.55^{* * *}$ & $-56.98^{* * *}$ & $-22.38^{* * *}$ & $-25.83^{* *}$ & $-34.40^{* * *}$ & -4.95 & $-18.40^{* *}$ & $-15.89^{*}$ \\
\hline & $(8.21)$ & $(9.90)$ & $(11.00)$ & $(7.07)$ & $(10.02)$ & $(11.31)$ & $(6.88)$ & $(7.78)$ & $(8.37)$ \\
\hline Constant & $\begin{array}{r}752.73^{* * * *} \\
(42.02)\end{array}$ & $743.49^{* * *}$ & $\begin{array}{r}743.69^{* * *} \\
(4100)\end{array}$ & $\begin{array}{r}931.59^{* * *} \\
(26.28)\end{array}$ & $\begin{array}{r}916.71^{* * *} \\
(34.18)\end{array}$ & $\begin{array}{r}902.70^{* * *} \\
(34.39)\end{array}$ & $\begin{array}{r}1025.43^{* * * *} \\
(2785)\end{array}$ & $\begin{array}{r}987.19^{* * *} \\
(29.65)\end{array}$ & $\begin{array}{r}984.29^{* * * *} \\
(29.63)\end{array}$ \\
\hline$A d j .-R^{2}$ & 0.31 & 0 & 0 & 0.20 & 0.20 & 0.2 & 0.36 & 0.38 & 0.40 \\
\hline No. Obs. & 356 & 356 & 356 & 772 & 772 & 772 & 755 & 755 & 755 \\
\hline
\end{tabular}

Notes: Table 5 documents the regression results for the Central Business Districts for buildings transacting for US $\$ 10$ million and greater. All results are reported in percentage points, where the coefficient has been pre-multiplied by 100 for ease of interpretation. Results reported are for the hedonic, SARAR and STARAR models specified in equations 1,3 and 5, respectively for transactions over the 2007 to 2013 period. Investor and seller types measure are relative to owner occupiers. Buying or selling transaction prices are per square foot. Periodic transaction price trends are reported for the 2008 to 2013 period with coefficients reporting the relative average transaction prices since 2007. 
Fig. 1: Geographic Distribution of Global Office Property Markets Transactions US \$10 million and Greater - 2007 to 2013

(a) London

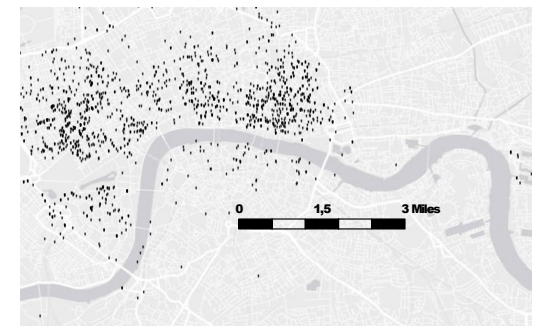

(c) Tokyo

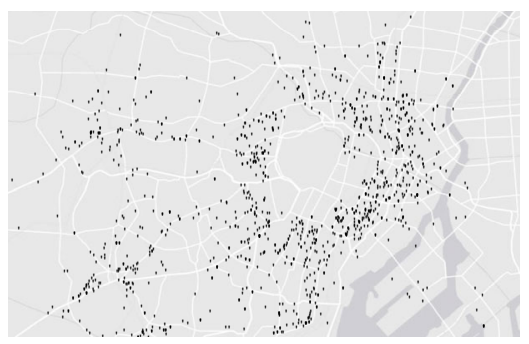

(e) New York City

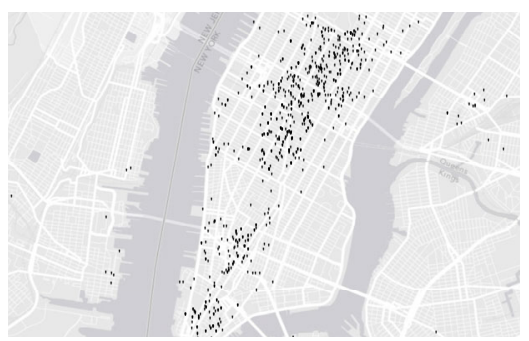

(b) Paris

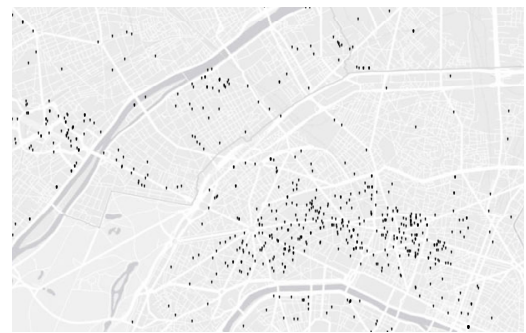

(d) Hong Kong

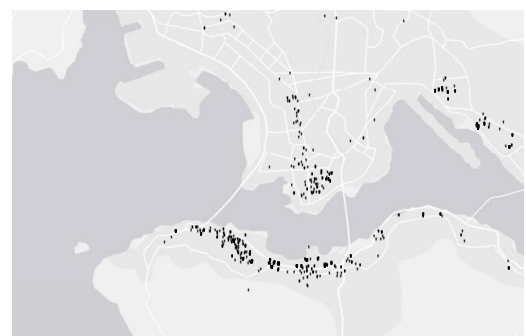

(f) Los Angeles

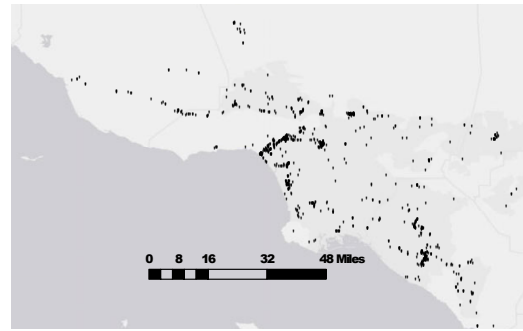

Notes: Figure 1 depicts the transaction sample's geographic distribution for the six largest property markets. Panels (1a) and (1b) display the distinct office market clusters of London and Paris. Panels (1c) and (1d) clearly shows the center of Tokyo and Hong Kong Island and Panels (1f) and (1e) depict the primary office market of New York City and Los Angeles property distribution over a vast geographic area. The scale for London, Paris, Tokyo, Hong Kong and New York City is set at one inch is three miles. However, for Los Angeles the scale is larger, where one inch is 48 miles. 
Fig. 2: Hedonic, Spatial and Spatial-Temporal Global Office Property Price Indicators

Transactions US \$ 10 million and Greater - 2007 to 2013

(a) London

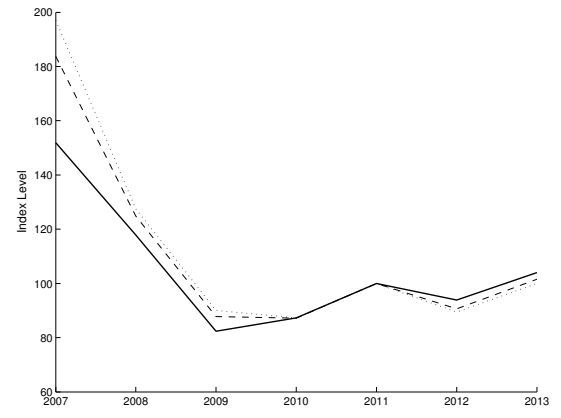

(c) Tokyo

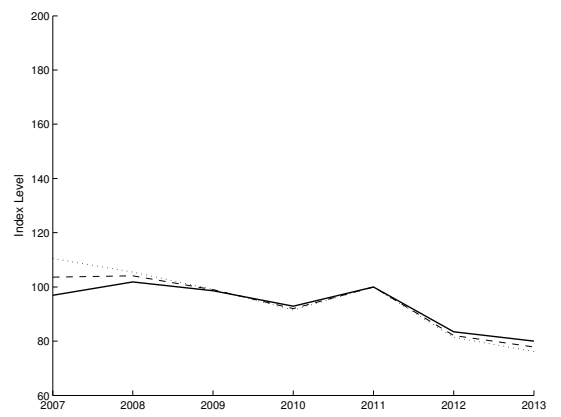

(e) New York City

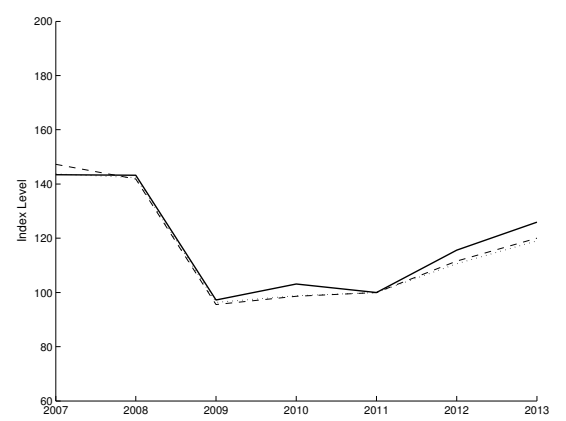

(b) Paris

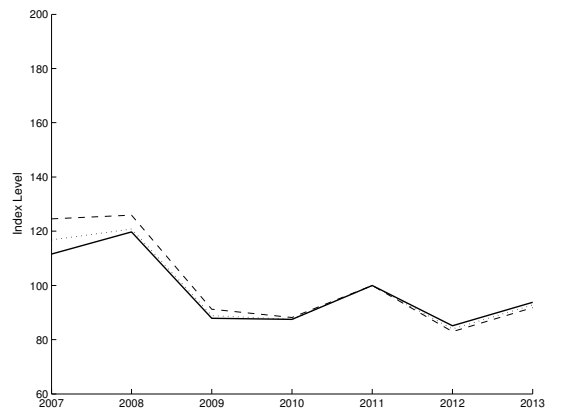

(d) Hong Kong

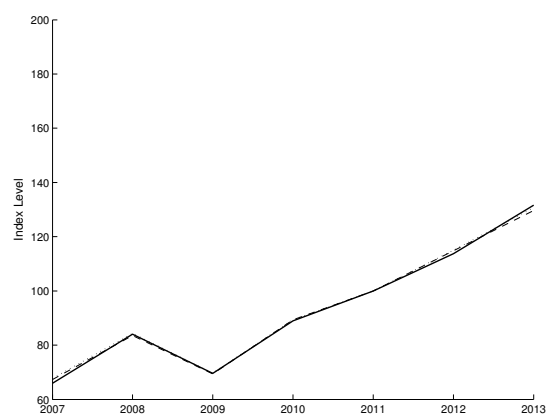

(f) Los Angeles

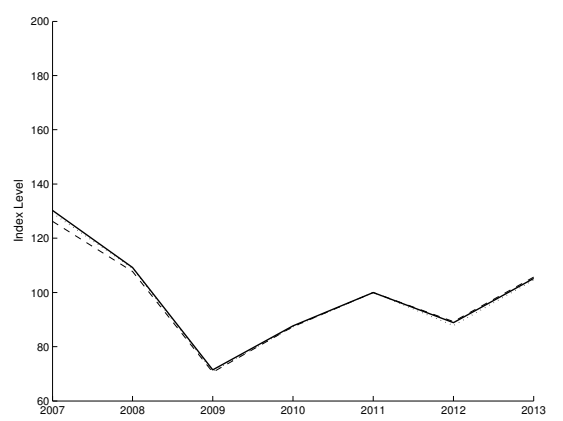

Notes: Figure 2 depicts the hedonic, spatial and spatial-temporal global office property price indicators for 2007 to 2013. The anti-logged time dummy estimates from the hedonic model, the spatial dependence model and the spatial-temporal dependence model at five nearest neighbors are depicted across the six global markets. Across all transaction price indices, 2011 is set as the base year. 


\section{A Location Dummies and CBD}

The market and sub-market breakdown for the six office markets is constructed as follows. For London, the first two to three letter pre-fix of their postal codes is used to delineate sub-markets, e.g., EC to represent London City. We estimate relative to the South bank. The CBD is denoted as Westminster and London City.

For Paris, the markets have been divided into the Parisian arrondissements and greater suburbs, where the CBD is transactions occurring in the Quartier Central des Affaires ( 8th Arrondissement), and La Defense (15th Arrondissement). The 1st, 8th, and 15th Arrondissements are used as the base case.

In Tokyo, the city is broken down into administrative wards. The CBD is designated as the combination of the Chiyoda, Chuo, Minato and Central Wards. The wards included in the CBD as well as the Shinjuku Ward are used as the base case.

For Hong Kong, the Admiralty and Central districts form the CBD. These districts as well as the West district are used as the base for relative location value estimates.

New York City's metro area is broken down into boroughs and then further disaggregated on Manhattan into Downtown, Midtown and Uptown. Downtown and Midtown Manhattan are used as the CBD for the New York City Metro area.

Finally, Los Angeles is defined by its zip-codes with "Old Downtown" and "New Downtown", e.g., zip codes 90017 and 90071 as the locations for the CBD. These zip-codes plus 90210 are designated as the base case. 


\section{B Spatial Estimation Procedure}

Estimation of the spatial models is carried out by using the efficient version of the Generalized Method of Moments estimator developed in Kelejian and Prucha (2010). We refer the reader to Kelejian and Prucha (2010) for details on the estimation procedure. In a first step, we use a two stage least squares (2SLS) approach to estimate the model parameters. Since the spatial and temporal components contain the log price per square foot as an argument they are endogenous regressors. To find suitable instruments for the spatial and temporal components we follow the discussion given in Kelejian and Prucha (2010), where for the SARAR model we note that the expected value of the endogenous regressors, i.e., the spatial and temporal dependence regressors, is a function of the exogenous components as shown in the following equation:

$$
E(W \log P)=\left(I-\rho_{1} W\right)^{-1} X \beta=\sum_{i=1}^{\infty} \rho_{1}^{i} W^{i} X \beta .
$$

Equation (6) shows that we can use the linearly independent columns $\left(X, W X, W^{2} X, T\right)$ as instruments, and Kelejian et al (2004) has shown that a limit of two polynomial expansions are sufficient. To avoid over-identification issues we also restrict the columns of the hedonic matrix used in the multiplication with the power series of the spatial weights to the log size and age. For the STARAR model, we use the same idea and use the first two elements of the power series of $L$ and $(W \odot L)$ when determining the instruments. Collecting the regressor variables $(W \log P, X, T)$ into the matrix $Z$ and the instruments into the matrix $H$ and use a 2 SLS estimator given by:

$$
\widetilde{\theta}=\left(\hat{Z}^{\prime} Z\right)^{-1} \hat{Z}^{\prime} \log P
$$

where in the first step, with vector $\widetilde{\theta}$ collecting the model parameters $\rho, \beta$, and $\delta$, and $\hat{Z}=H\left(H^{\prime} H\right)^{-1} H^{\prime} Z$. In the second step, the errors estimated using the first step 2SLS estimate are used to construct a nonlinear moments estimator for the spatial error parameter. The non-linear estimator for the spatial error parameter $\lambda$ is found by minimizing the following criterion function:

$$
\min _{\lambda}\left\{(\gamma-\Gamma \alpha)^{\prime} \Psi(\gamma-\Gamma \alpha)\right\}
$$

where $\gamma$ and $\Gamma$ are a $2 \times 1$ vector and a $2 \times 2$ matrix, respectively. The vector $\alpha$ contains $\lambda$ and $\lambda^{2}$ as elements. The elements of $\gamma$ and $\Gamma$ are given by:

$$
\begin{aligned}
\Gamma_{11} & =\frac{2}{N} u^{\prime} W^{\prime}\left(W^{\prime} W-\operatorname{diag}\left(w_{i}^{\prime} w_{i}\right)\right) u, & \Gamma_{21} & =\frac{1}{N} u^{\prime} W^{\prime}\left(W-W^{\prime}\right) u, \\
\Gamma_{12} & =\frac{-1}{N} u^{\prime} W^{\prime}\left(W^{\prime} W-\operatorname{diag}\left(w_{i}^{\prime} w_{i}\right)\right) W u, & \Gamma_{22} & =\frac{-1}{N} u^{\prime} W^{\prime} W W u, \\
\gamma_{1} & =\frac{1}{N} u^{\prime}\left(W^{\prime} W-\operatorname{diag}\left(w_{i}^{\prime} w_{i}\right)\right) u, & \gamma_{2} & =\frac{1}{N} u^{\prime} W u,
\end{aligned}
$$

and $\Psi$ denotes the inverse of the covariance matrix of the two moment conditions which depends on the spatial error parameter $\lambda$. We use a first inefficient estimator for $\lambda$ were we set the matrix $\Psi$ equal to the identity matrix. A second efficient estimator for $\lambda$ is found by using the matrix $\Psi$ in the function given in (8). To determine the elements of $\Psi$ we define the following:

$$
\begin{aligned}
\epsilon & =(I-\lambda W) u \\
\Sigma & =\operatorname{diag}\left(\epsilon_{i}^{2}\right) \\
\tilde{\alpha}_{r} & =\frac{1}{N}\left[-Z^{\prime}\left(I-\lambda W^{\prime}\right)\left(A_{r}+A_{r}^{\prime}\right)(I-\lambda W) u\right] \\
\tilde{T}_{r} & =\left(I-\lambda W^{\prime}\right)^{-1} H\left(\frac{1}{N} H^{\prime} H\right)^{-1}\left(\frac{1}{N} H^{\prime} Z\right)\left[\left(\frac{1}{N} Z^{\prime} H\right)\left(\frac{1}{N} H^{\prime} H\right)^{-1}\left(\frac{1}{N} H^{\prime} Z\right)\right]^{-1}, \\
\tilde{a}_{r} & =T \tilde{\alpha}_{r}
\end{aligned}
$$


where the index $r=1,2, A_{1}=W^{\prime} W-\operatorname{diag}\left(w_{i}^{\prime} w_{i}\right)$ and $A_{2}=W$. Given these relations we have an estimator for the matrix $\Psi$ given by:

$$
\Psi_{r s}=\frac{1}{2 N} \operatorname{trace}\left[\left(A_{r}+A_{r}^{\prime}\right) \Sigma\left(A_{s}+A_{s}^{\prime}\right) \Sigma\right]+\frac{1}{N} \tilde{a}_{r}^{\prime} \Sigma \tilde{a}_{s},
$$

with $r, s=1,2$. A second efficient estimator for $\lambda$ is found by minimizing the function given in Equation (8) using $\Psi$ as weighting matrix. The standard deviation of the efficient estimator of the spatial error parameter is given by:

$$
\Sigma_{\lambda}=\frac{1}{N}\left(J^{\prime} \Psi J\right)^{-1}
$$

where $J=\Gamma\left[\begin{array}{c}1 \\ 2 \lambda\end{array}\right]$. In the third step, we use the estimated spatial error parameter to perform a Cochrane-Orcutt type transformation, i.e., we use $\widetilde{\log P}=\log P-\lambda W \log P$ and $\widetilde{Z}=Z-\lambda W Z$ instead of $\log P$ and $Z$ in the 2SLS procedure given in (7).

Acknowledgements For research assistance we thank Ruud Weerts. For guidance and constructive comments we thank the participants at the MNM conference as well as our insightful discussant Albert Saiz. Moreover, we are grateful for the comments from the anonymous referee whose comments enhanced our manuscript. All errors or omissions remain that of the authors. 